\title{
Patents and the Progress of Science: Exclusive Rights and Experimental Use $\uparrow$
}

\author{
Rebecca S. Eisenberg††
}

The patent laws confer exclusive rights in inventions and discoveries in furtherance of a constitutional purpose "To Promote the Progress of Science and useful Arts." Yet the idea that exclusive rights in new knowledge will promote scientific progress is counterintuitive to many observers of research science, who believe that science advances most rapidly when the community enjoys free access to new discoveries. ${ }^{2}$ These divergent perspectives on how best to promote scientific progress potentially conflict when subsequent investigators use patented inventions in their research.

In theory, one might expect each of these perspectives to predominate in its own separate sphere of basic or applied research. $^{3}$ In the basic research sphere, academic scientists could publish their discoveries to the scientific community and build on each other's prior research without fear of infringement liability, while in the applied research sphere, industrial scientists could keep their discoveries secret or patent them for exclusive commercial development by their employers. But in practice these two

$\dagger$ Copyright 1989 Rebecca S. Eisenberg

I† Professor of Law, University of Michigan Law School. I wish to thank Marty Adelman, Severin Borenstein, Ed Cooper, Avery Katz, Jim Krier, Rick Lempert, Jeff MacKieMason, Rob Merges, Roger Noll, Sallyanne Payton, Don Regan, and Fred Schauer for helpful comments on earlier drafts of this article. I am also grateful to Cathy Bencivengo and Jeffrey Mills for many hours of research assistance.

1 US Const, Art I, § 8, cl 8.

2 See, for example, Robert K. Merton, The Normative Structure of Science, in Robert K. Merton, The Sociology of Science 267, 273-75 (Chicago, 1973); Jerome R. Ravetz, Scientific Knowledge and its Social Problems 245-59 (Oxford, 1971); Bernard Barber, Science and the Social Order 90-93 (Free Press, 1952). See also notes 120-207 and accompanying text.

3 By "basic research" I mean research directed solely toward expanding human knowledge, and by "applied research" I mean research directed toward solving practical problems. See Norman W. Storer, The Social System of Science 106-16 (Holt, Rinehart, 1966); Warren O. Hagstrom, The Scientific Community 108-9 (Basic Books, 1965); William Kornhauser, Scientists in Industry: Conflict and Accommodation 16-17 (U Cal, 1963). The operation of the patent laws has traditionally been confined to applied research. See Rebecca $\mathrm{S}$. Eisenberg, Proprietary Rights and the Norms of Science in Biotechnology Research, 97 Yale L J 177, 184-87 (1987). 
spheres often overlap. The distinction between basic and applied research is particularly difficult to maintain in contemporary research in the biomedical sciences. ${ }^{5}$ The biotechnology revolution has accelerated the commercial development of basic research discoveries and attracted commercial interest in academic biomedical research in its early stages. Academic and industrial scientists may thus have a shared interest in developing and using new laboratory techniques and equipment, or in isolating and developing new ways of producing proteins that are potentially useful in the study or treatment of human disease. As a consequence, academic researchers make and patent commercially valuable discoveries, and researchers in industry make and patent discoveries that are important to the work of scientists seeking knowledge for its own sake. Important research discoveries in the biomedical sciences are increasingly likely to be patented, and the use of these discoveries in subsequent research is increasingly likely to threaten the commercial interests of patent holders.

If basic research cannot be insulated from the patent system entirely, it might still be possible to reconcile a system of exclusive patent rights in prior discoveries with the interest of the scientific community in allowing subsequent researchers to enjoy free access to such discoveries by exempting the use of patented inventions in research from infringement liability. While the United States patent statute does not provide such an exemption, ${ }^{6}$ the courts have

4 See Kornhauser, Scientists in Industry at 16-17 (cited in note 3); Richard R. Nelson, The Link Between Science and Invention: The Case of the Transistor, in National Bureau of Economic Research, The Rate and Direction of Inventive Activity 549, 581-83 (Princeton, 1962); Seymour Melman, The Impact of the Patent System on Research, Subcomm on Patents, Trademarks, and Copyrights of the Senate Comm on the Judiciary, Study No 11, 85th Cong, 2d Sess 7-8 (GPO, 1958).

See Eisenberg, 97 Yale L J at 195-97 (cited in note 3).

- I refer to the basic utility patent statute codified at 35 USC $\$ 100$ et seq (1982). Since the enactment of the Drug Price Competition and Patent Term Restoration Act of 1984, the patent statute has provided a limited exemption from infringement liability for those who make, use, or sell a patented invention "solely for uses reasonably related to the development and submission of information under a Federal law which regulates the manufacture, use, or sale of drugs." 35 USC $\S 271$ (e) (Supp 1986). The courts so far have construed this provision narrowly. See, for example, Scripps Clinic and Research Foundation v Genentech Inc., 666 F Supp 1379, 1395 (N D Cal 1987), 678 F Supp 1429 (N D Cal 1988) (discussed at notes 235-48 and accompanying text). But a recent decision of the Court of Appeals for the Federal Circuit extending the exemption to clinical testing of medical devices may portend greater judicial receptiveness to other broadening constructions. See Eli Lilly \& Co. $v$ Medtronic, Inc., 10 USPQ 2d 1304 (Fed Cir 1989).

Other intellectual property statutes provide broader experimental use exemptions. See, for example, Plant Variety Protection Act of 1970, 7 USC § 2544 (1982) ("The use and reproduction of a protected variety for plant breeding or other bona fide research shall not 
long recognized, at least in principle, that a purely "experimental use" of a patented invention, with no commercial purpose, should be exempt from infringement liability. ${ }^{7}$ But since the use of patented inventions in noncommercial research rarely provokes a lawsuit, most of the judicial decisions considering the scope of the experimental use exemption have involved disputes between commercial competitors. Within this universe of cases the experimental use defense has been frequently raised but rarely sustained..$^{8}$ For the most part, the courts have held that the experi-

constitute an infringement of the protection provided under this chapter"); Semiconductor Chip Protection Act of 1984, 17 USC § 906(a) (Supp 1986) (exempting from infringement liability the reproduction of a protected work "solely for the purpose of teaching, analyzing, or evaluating the concepts or techniques" embodied therein or the creation of an original work incorporating the results of such analysis or evaluation). See also Atomic Energy Act of 1946, ch 724, § 11(b), 60 Stat 753, 768 (1946) ("No patent hereafter granted shall confer any rights with respect to any invention or discovery to the extent that such invention or discovery is used in the conduct of research or development activities in the fields specified in section 3 directing Atomic Energy Commission to insure continued conduct of research and development in fields of [nuclear processes, theory and production of atomic energy]"). This provision was eliminated in a substantial revision of the patent provisions in the Atomic Energy Act of 1954, Pub L No 703, ch 1073, $\S$ 151-160, 68 Stat 919, 943-48 (1954), current version codified at 42 USCA $\S \S 2181-2190$ (1982 \& Supp 1988).

The patent laws of many other countries, including Japan and most members of the European Economic Community, recognize an experimental use exemption that is not limited to specific fields of technology. Stephen A. Bent, et al, Intellectual Property Rights in Biotechnology Worldwide 342-45 (Stockton, 1987), citing European Community Patent Convention Art 31(b) (which provides that patent protection shall not extend to "acts done for experimental purposes relating to the subject-matter of the patented invention"). Germany, France, the United Kingdom, Italy, the Netherlands, Belgium, Luxembourg, Ireland, Greece and Spain have either amended their national patent laws to conform with Article 31(b) of the Community Patent Convention or have legislation pending to achieve this effect. See also Japanese Patent Law of 1978 Art 69(1).

The U.S. copyright laws also exempt some research uses of copyrighted works from infringement liability under the "fair use" doctrine. 17 USC $\$ 107$ (1982) ("the fair use of a copyrighted work ... for purposes such as . . scholarship, or research, is not an infringement of copyright"). See also Williams \& Wilkins v U.S., $487 \mathrm{~F} 2 \mathrm{~d} 1345,1362$ (Ct Cl 1973) (holding that the fair use doctrine exempts from copyright infringement liability the photocopying of copyrighted articles in medical journals for the use of government medical researchers).

7 Roche Products, Inc. v Bolar Pharmaceutical Co., 733 F2d 858, 862-63 (Fed Cir 1984); Pfizer, Inc. v International Rectifier Corp., 217 USPQ 157, 160-61 (C D Cal 1982). See generally Donald S. Chisum, 4 Patents § 16.03(1) (Bender, 1988); Ronald D. Hantman, Experimental Use as an Exception to Patent Infringement, $67 \mathrm{~J}$ Pat Off Soc'y 617 (1985); Richard E. Bee, Experimental Use as an Act of Patent Infringement, $39 \mathrm{~J}$ Pat Off Soc'y 357 (1957).

- See, for example, Roche Products, 733 F2d at 862-63 (use of patented drug by generic drug manufacturer in performing clinical tests of drug prior to expiration of patent constituted patent infringement); Spray Refrigeration Co. v Sea Spray Fishing, Inc., 322 F2d 34, 36-37 (9th Cir 1963) (use of patented apparatus and method for freezing fish "for the purpose of experimentation as to the desirability of using this method" constituted patent infringement where use occurred in course of commercial fishing operation of kind which pat- 
mental use defense does not apply to the facts of the particular cases before them. As a consequence, the purpose and scope of the experimental use defense are not well defined. As the use of patented inventions becomes increasingly important to the progress of research science and increasingly threatening to the interests of patent holders, this vaguely defined doctrine is becoming less satisfactory. The issue has begun to command the attention of the bar, ${ }^{\circ}$ commentators, ${ }^{10}$ and Congress. ${ }^{11}$

ent was designed to serve); Pfizer, 217 USPQ at 160-62 (use of patented drug by generic drug manufacturer in performing clinical tests of drug prior to expiration of patent constituted patent infringement); Imperial Chem. Ind., PLC v Henkel Corp., 545 F Supp 635, 656 (D Del 1982) (defendant's manufacture of 1200 pounds of patented chemicals for "pilot plant use" infringed patent where defendant supplied samples to potential customers and made it known in market that chemicals were commercially available); Northill Co. v Danforth, 51 F Supp 928, 929 (N D Cal 1942) ("Defendant's experiments were evidently not made for philosophical or amusement purposes but were made in connection with his business as a manufacturer and salesman of anchors"); Sprout, Waldron \& Co. v Bauer Bros. Co., 26 F Supp 162, 169 (S D Ohio 1938) ("The defendant cannot escape on the ground of experimental use where the machines were used to operate upon customers' products in the ordinary course of business"); R.C.A. v Andrea, 15 F Supp 685, 687 (E D NY 1936), mod'd on other grounds, $90 \mathrm{~F} 2 \mathrm{~d} 612$ (2d Cir 1937) (assembling parts of patented combination to test them was infringement where assembly was "not a scientific research or an engineering inquiry" but rather "a step which the defendants apparently deemed necessary in the manufacture and sale of their product"); Pairpearl Prods., Inc. $v$ Joseph H. Meyer Bros., 58 F2d 802,804 (S D Me 1932) (use of patented process for extracting pearl essence infringed patent notwithstanding defendant's claim that use was experimental as incident to search for new agent, where pearl essence extracted through patented process was sold to customers); Cimiotti Unhairing Co. $v$ Derboklow, 87 F 997, 999 (E D NY 1898) (use of patented machine for customers "in the ordinary course of business" was patent infringement, notwithstanding defendant's claim that he was "experimenting" with machines in order to see if he could improve them); United States Mitis Co. v Carnegie Steel Co., 89 F 343, 351 (W D Pa 1898) (noting that defendant's use of patented invention "was a commercial use, extending over a period of several months, and involved a very large product"); Bonsack Machine Co. $v$ Underwood, 73 F 206, 211 (E D NC 1896) (noting that machine "has not been made simply as an experiment, but has been used for profit, that is, for the purpose of selling the [defendant's] patent"); Albright v Celluloid Harness-Trimming Co., 1 F Cases 320, 323 (C C NJ 1877) (holding use of patented invention in trial manufacture "is a technical infringement, and is sufficient to authorize an injunction restraining [defendant's] future use" but not sufficient for award of damages); Poppenhusen v Falke, 19 F Cases 1048, 1049 (S D NY 1861) (finding infringement in spite of experimentation claim and noting that defendants "are rivals of the complainant in the very business to which his patents relate").

${ }^{9}$ See Experimental Use After Roche v Bolar, 1988 ABA Patent, Trademark \& Copyright Committee Rep at 25-28 (Proposed Resolution 101-4) ("RESOLVED, that the Section of Patent, Trademark \& Copyright Law favors in principle an exemption from infringement for experimental or research use, not limited to pharmaceutical products, whether or not such use is conducted by a commercial organization").

${ }^{10}$ See Robert P. Merges, Intellectual Property in Higher Life Forms: The Patent System and Controversial Technologies, $47 \mathrm{Md}$ L Rev 1051, 1073-75 (1988); Donald S. Chisum, The Patentability of Algorithms, 47 U Pitt L Rev 959, 1017-18 (1986); see generally Hantman, $67 \mathrm{~J}$ Pat Off Soc'y 217 (cited in note 7); Ned A. Israelsen, Making, Using and Selling Without Infringing: An Examination of 35 U.S.C. Section 271(e) and the Experi- 
In this article I analyze the proper scope of an experimental use exemption from patent infringement liability by comparing the rationales behind promoting technological progress through granting exclusive patent rights in inventions with competing arguments for promoting scientific progress by allowing all investigators to enjoy free access to the discoveries of other scientists.

I begin by reviewing key features of the patent laws and theoretical justifications for granting patent monopolies in order to clarify the implications of existing patent doctrine and theory for an experimental use exemption. I then look to the literature in the sociology, history, and philosophy of science for reasons to permit researchers to have free access to prior scientific discoveries.

With this background, I offer suggestions on the proper scope of an experimental use defense in light of the purposes of the patent laws and the needs of the research science community. I conclude by using two recently patented inventions with obvious implications for future biomedical research as examples to illustrate which research uses should be subject to the control of the patent holder and which uses should be allowed to proceed without a license.

\section{The Case for Exclusive Rights}

\section{A. The Experimental Use Exemption in Context}

A United States patent confers the exclusive right to make, use, and sell the invention set forth in the patent claims in the United States for seventeen years. ${ }^{12}$ During the term of the patent the patent holder has the right to stop anyone from using the invention-even an innocent infringer who develops the same invention independently. ${ }^{13}$ Patent holders need not exploit their exclusive rights themselves, but may sell or license them to others in

mental Use Exception to Patent Infringement, 16 AIPLA Q J 457 (1988-89).

11 Transgenic Animal Patent Reform Act, HR Rep No 100-888, 100th Cong, 2d Sess 4951 (1988) (bill as originally drafted would have exempted from patent infringement liability the use of patented transgenic animals "solely for research or experimentation without any commercial intent or purpose"); 134 Cong Rec H 7439 (Sept 13, 1988) (statement of Rep. Rose in favor of HR 4970).

1235 USC \$ 154 (1982).

$1 s 35$ USC \& 271 (1982); Robert L. Harmon, Patents and the Federal Circuit 110-11 (Bureau of Nat Aff, 1988). Remedies available may be more restricted in the case of innocent infringers. See 35 USC $\S 287$ (1982) (if patent holder or licensees fail to mark patented articles with word "patent" and number of patent, no damages may be recovered in infringement action except upon proof of continued infringement after actual notice of patent). 
exchange for royalties, ${ }^{14}$ or even use their patents to suppress the underlying inventions entirely. ${ }^{15}$

In exchange for these exclusive rights, the patent statute requires the inventor to disclose the invention in the patent application in terms sufficient to enable others who are "skilled in the art" to make and use it. ${ }^{16}$ This enabling disclosure becomes freely available to the public as soon as the patent issues; the patent holder may not thereafter monitor or control access to it. ${ }^{17}$ Judicial decisions characterize the enabling disclosure in the patent as the "quid pro quo" of the patent monopoly. ${ }^{18}$ In order to obtain a patent, the applicant must first contribute "a measure of worthwhile knowledge to the public storehouse."19

Although the patent statute on its face grants the patent holder the unqualified right to exclude others from using the invention until after the patent expires, the timing of the disclosure requirement suggests that there are limits to the patent holder's exclusive rights even during the patent term. If the public had absolutely no right to use the disclosure without the patent holder's consent until after the patent expired, it would make little sense to require that the disclosure be made freely available to the public at the outset of the patent term. The fact that the patent statute so plainly facilitates unauthorized uses of the invention while the patent is in effect suggests that some such uses are to be permitted. This inference is fortified by cases recognizing, at least in principle, that certain experimental uses of patented inventions should not give rise to infringement liability. ${ }^{20}$

1435 USC \$ 261 (1982).

15 Continental Paper Bag Co. v Eastern Paper Bag Co., 210 US 405 (1907).

1635 USC §§ 111, 112 (1982).

17 See In re Lundak, 773 F2d 1216, 1222-23 (Fed Cir 1985) (by the time patent issues, materials that are necessary to make and use invention must be freely available to public without having to get them from patentee, although availability from patentee is adequate while patent application is pending); See generally White Consol. Indus. $v$ Vega Servo-Control, 713 F2d 788 (Fed Cir 1983) (disclosure that incorporates trade secret available only by license from patentee fails to satisfy the statute). But see, Patent and Trademark Office Proposed Rule on Deposit of Biological Materials § 1.207(b), 53 Fed Reg 39420, 39431 (1988), to be codified at 37 CFR $\S 1.207$ (b) (permitting patent holders who deposit biological materials with independent depository in satisfaction of patent disclosure requirement to monitor access to the deposit by contracting with the depository to notify depositor of any request for the materials along with the name and address of the party to whom the sample was furnished).

${ }^{18}$ See generally United States v Dubilier Condenser Corp., 289 US 178, 186-87 (1933); Grant v Raymond, 31 US (6 Pet) 218, 247 (1832).

19 Application of Argoudelis, 434 F2d 1390, 1394 (Ct Cust Pa 1970) (Baldwin concurring).

${ }^{20}$ See cases cited in notes 7-8. 
The experimental use defense first appeared in dictum in the 1813 case of Whittemore $v$ Cutter. ${ }^{21}$ The author of the opinion, Justice Story, observed that "it could never have been the intention of the legislature to punish a man, who constructed a [patented] machine merely for philosophical experiments, or for the purpose of ascertaining the sufficiency of the machine to produce its described effects."22 Subsequent courts have consistently recognized the existence of an experimental use defense in theory, although the defense has almost never succeeded in practice.

Recent case law suggests that the experimental use defense may be available only for "pure" research with no commercial implications. In Roche Products $v$ Bolar Pharmaceutical Co. ${ }^{23}$ the Federal Circuit rejected the argument of a generic drug manufacturer that the defense applied to its use of a patented drug during the patent term to conduct clinical tests. The purpose of the tests was to gather data necessary to obtain FDA approval to market a generic version of the drug as soon as the patent expired. Characterizing the experimental use defense as "truly narrow," the court noted that the defendant's use of the drug was "no dilettante affair such as Justice Story envisioned." 24 The court held that the defense does not permit "unlicensed experiments conducted with a view to the adaption of the patented invention to the experimentor's business," as opposed to experiments conducted "for amusement, to satisfy idle curiosity, or for strictly philosophical inquiry."2s This language suggests that under the present state of the law the defense is unavailable whenever the defendant's research is motivated by a commercial purpose. As a practical matter, this could be a very significant limitation on the defense in fields of research with commercial significance, in which even academic research will often be motivated at least in part by commercial interests. ${ }^{26}$ At the same time, this formulation of the exemption may be

$2229 \mathrm{~F}$ Cases 1120 (D Mass 1813).

22 Id at 1121.

23 733 F2d 858 (Fed Cir 1984).

14 Id at 863.

25 Id. Congress has since abrogated the rule of Roche insofar as it pertains to generic drug manufacturers, but left the experimental use aspect of the decision intact. 35 USC $\S$ 271(e). See note 6.

26 Academic researchers whose work is funded by industry are likely to be motivated by "philosophical" and "commercial" interests at the same time. Even in government-sponsored academic research, universities and researchers stand to profit by making and patenting commercially valuable discoveries, creating an incentive for researchers to keep an eye out for potential commercial applications of their work. See generally Eisenberg, 97 Yale L J at $195-97$ (cited in note 3 ). 
quite broad in the case of research technology inventions with significant markets among "strictly philosophical" researchers, depriving some patent holders of the opportunity to collect royalties from a sizable fraction of their potential customers.

\section{B. Exclusive Rights in Exchange for Invention and Disclosure}

In order to assess the wisdom of exempting the use of patented inventions in research from the scope of the patent monopoly, it is first necessary to understand exactly how patent monopolies function to promote progress. It makes little sense to create or expand exceptions to the exclusive rights conferred by patents if such exceptions would undermine essential functions of the patent system.

The United States Constitution posits an instrumental justification for patents, allowing Congress to enact patent legislation for the specific purpose of promoting scientific progress. ${ }^{27}$ In analyzing how patents promote scientific progress, the courts have emphasized two mechanisms: first, the prospect of obtaining a patent monopoly provides an incentive to invest in research to make new inventions; and second, the patent system promotes disclosure of new inventions and thereby enlarges the public storehouse of knowledge. ${ }^{28}$ Both of these theories have been elaborated and challenged in the economics literature. ${ }^{29}$

\section{Incentive to invent.}

The incentive to invent theory holds that too few inventions will be made in the absence of patent protection because inven-

27 US Const, Art I, § 8, cl 8. This instrumental justification is distinct from moral arguments for patent protection advanced in some European countries, notably France, in the nineteenth century, such as the argument that inventors have a natural property right in their ideas that society is morally obligated to recognize. See generally Fritz Machlup and Edith Penrose, The Patent Controversy in the Nineteenth Century, $10 \mathrm{~J}$ Econ Hist 1, 10-20 (1950). The framers of the United States Constitution rejected the notion that inventors have a natural property right in their inventions. Thus Thomas Jefferson wrote:

Inventions then cannot, in nature, be a subject of property. Society may give an exclusive right to the profits arising from them, as an encouragement to men to pursue ideas which may produce utilities, but this may or may not be done according to the will and convenience of society, without claim or complaint from anybody.

See Walter Hamilton, Investigation of Concentration of Economic Power: Patents \& Free Enterprise 21 (TNEC Monograph No 31) (GPO, 1941) (quoting Thomas Jefferson).

${ }_{28}$ Kewanee Oil Co. $v$ Bicron, 416 US 470, 480-81 (1974).

29 A third theory, that patents promote "innovation" or investment in the commercial development of inventions, has been advanced by some commentators but has received little attention from the courts. See notes 81-118 and accompanying text. 
tions once made are easily appropriated by competitors of the original inventor who have not shared in the costs of invention. ${ }^{30}$ If successful inventions are quickly imitated by free riders, competition will drive prices down to a point where the inventor receives no return on the original investment in research and development. ${ }^{31}$ As a result, the original inventor may be unable to appropriate enough of the social value of the invention to justify the initial research and development expenditures. ${ }^{32}$ The high risk involved in research compounds the likelihood of underinvestment in invention..$^{33}$ Thus inventions with potentially great social benefits might never come about, or at least might be significantly delayed, unless private returns to invention were increased above their free market levels. Patents serve to bring the private benefits of inven-

so See Ward S. Bowman, Jr., Patent and Antitrust Law 2-3 (Chicago, 1973); Frederic M. Scherer, Industrial Market Structure and Economic Performance 379-99 (Rand McNally, 1970); John S. McGee, Patent Exploitation: Some Economic and Legal Problems, $9 \mathrm{~J}$ L \& Econ 135 (1966); Dan Usher, The Welfare Economics of Invention, 31 Economica 279 (1964); Kenneth J. Arrow, Economic Welfare and the Allocation of Resources for Invention, in Rate and Direction of Inventive Activity at 609 (cited in note 4); Richard R. Nelson, The Economics of Invention: A Survey of the Literature, $32 \mathrm{~J}$ Bus 101 (1959); Fritz Machlup, An Economic Review of the Patent System, Subcomm on Patents, Trademarks, and Copyrights of the Senate Comm on the Judiciary, Study No 15, 85th Cong, 2d Sess (GPO, 1958); Machlup and Penrose, $10 \mathrm{~J}$ Econ Hist at 20-25 (cited in note 27); Michael Polanyi, Patent Reform, 11 Rev of Econ Studies 61 (1944); Arnold Plant, The Economic Theory Concerning Patents for Inventions, 1 Economica 30 (1934).

${ }^{31}$ The costs of research and development leading to a new invention are one-time, "sunk" costs. Once the invention has been made and disclosed, the marginal cost of using more intensively the knowledge gained through prior research is zero. There may still be other variable costs associated with producing goods and services through use of the invention, such as costs for labor and materials, but the invention cost is fixed in the past and need not be incurred again no matter how intensively the invention is used. In a competitive market in which anyone is free to use the invention to produce goods without obligation to the inventor, the cost of the goods sold will be driven down to a price approaching the marginal cost of their production, and thus the selling price will not allow for any return on the sunk cost of the research and development necessary to make the invention in the first place. See Machlup, Subcomm on Patents, Study No 15 at 58-59 (cited in note 30).

32 See Scherer, Industrial Market Structure at 384 (cited in note 30); William F. Baxter, Legal Restrictions on Exploitation of the Patent Monopoly: An Economic Analysis, 76 Yale L J 267, 268-69 (1966); Machlup, Subcomm on Patents, Study No 15 at 57-58 (cited in note 30 ).

ss Arrow, Economic Welfare at 614-15 (cited in note 30); Richard R. Nelson, The Simple Economics of Basic Scientific Research, $67 \mathrm{~J}$ Pol Econ 297 (1959). Arrow suggests that since the output of inventive effort is uncertain, and since there is no adequate market mechanism for shifting this risk, risk aversion can be expected to lead to underinvestment in invention. Arrow, Economic Welfare at 611-14, 616. McGee argues that inventors may display risk preference and therefore overinvest in inventive activity. McGee, $9 \mathrm{~J} \mathrm{~L}$ Econ at 136 (cited in note 30). See Edwin Mansfield, et al, Research and Innovation in the Modern Corporation 18-63 (Norton, 1971) (finding that firms tend to invest only in R\&D projects with high estimated probability of success, but that firms tend to overpredict success). 
tions in line with their social value by allowing inventors to use their monopoly positions to extract a price that more closely approaches the value that users receive from inventions. ${ }^{34}$

Challenges to the incentive to invent justification for patents have taken a variety of forms. The most fundamental objection is that subjecting new inventions to monopoly control restricts their use and thereby reduces the social benefits of patented inventions. ${ }^{35}$ It is open to question whether it is necessary to endure the output-restricting effects of patent monopolies in order to stimulate invention. ${ }^{36}$ In some cases the head start advantage gained by being first in the market with a new invention may provide a sufficient incentive to promote investment in research. ${ }^{37}$ Similarly, the need to keep up with the technological progress of market rivals

${ }^{34}$ See Baxter, 76 Yale $L J$ at 270 (cited in note 32). An extreme version of this argument (attributed to John Stuart Mill) is that a patent holder can never use the patent monopoly to extract more than the value of the inventor's efforts to society, since consumers will pay the patent holder no more than the invention is worth to them. See Machlup and Penrose, $10 \mathrm{~J}$ Econ Hist at 20 (cited in note 27). This argument rests on the often dubious assumption that the invention would never have been made were it not for the efforts of the inventor who patented it. If instead one assumes that somebody else would eventually have made the same invention, it is no longer clearly appropriate to attribute the full social value of the invention to the efforts of the first inventor. See Bowman, Patent and Antitrust Law at 17 (cited in note 30 ).

35 See Scherer, Industrial Market Structure at 382 (cited in note 30); Baxter, 76 Yale L $\mathrm{J}$ at 270, 274 (cited in note 32); Machlup, Subcomm on Patents, Study No 15 at 55, 63 (cited in note 30); Polanyi, 11 Rev of Econ Studies at 62 (cited in note 30).

${ }^{38}$ Some critics of the patent system have suggested that government could stimulate invention at less social cost by awarding prizes to inventors in lieu of patents. See, for example, Polanyi, 11 Rev of Econ Studies at 65 (cited in note 30). Machlup states that such proposals for alternatives to patents are almost as old as the patent system, and notes that James Madison proposed a system of prizes and bonuses to inventors in lieu of patents at the Constitutional Convention in 1787. Machlup, Subcomm on Patents, Study No 15 at $15 \mathrm{n}$ 83 (cited in note 30); see also Hamilton, Patents and Free Enterprise at 24-25 (cited in note 27).

Others have argued that inventions arise inevitably with or without government incentives when the state of basic knowledge and other social conditions become favorable. See Abbott P. Usher, A History of Mechanical Inventions 1-31 (McGraw Hill, 1929); S.C. Gilfillan, The Sociology of Invention 71-78 (Follett, 1935); William F. Ogburn, Social Change 86 (Huebsch, 1923); Machlup, Subcomm on Patents, Study No 15 at 23 n 120, 24 n 127 (cited in note 30); Alfred E. Kahn, Fundamental Deficiencies of the American Patent Law, $30 \mathrm{Am}$ Econ Rev 475, 479-81 (1940).

37 Scherer, Industrial Market Structure at 384-87 (cited in note 30); Machlup, Subcomm on Patents, Study No 15 at 23 n 121, 24 n 128, 38-39 and sources cited therein, 59-60 (cited in note 30). See generally Jack Hirshleifer, The Private and Social Value of Information and the Reward to Inventive Activity, 61 Am Econ Rev 561 (1971) (arguing that apart from the profits obtained from patents, innovators may profit by using their advance knowledge, or "foreknowledge," of new technologies to speculate in assets whose value will be affected by the release of the new technology). 
might stimulate invention without further incentives, ${ }^{38}$ or non-patent barriers to market entry may give enough protection from competition to make research and development profitable without patents. $^{39}$

Another objection to the incentive to invent justification is that patent incentives may distort economic activity in ways that undermine efficiency. For example, competing firms hoping to make patentable inventions ahead of their rivals in order to win lucrative patents may spend too much money trying to develop inventions quickly, when the same result could be achieved at less social cost through a less accelerated research effort. ${ }^{40}$ The patent system may divert too many resources away from productive activities in which returns are limited by the forces of competition, ${ }^{41}$ or it may divert resources from research in fields where patent protection is unavailable to research that is more likely to yield profitable patent monopolies. ${ }^{42}$

Finally, some writers have argued that the patent system may hinder progress through its effects on the research efforts of persons other than the patent holder. The existence of a patent may undermine the incentives of these other persons to make improvements in patented technologies. ${ }^{43}$ Worse yet, it may force competi-

\footnotetext{
ss Scherer, Industrial Market Structure at 386 (cited in note 30); Machlup, Subcomm on Patents, Study No 15 at 38-39 (cited in note 30).

39 Scherer, Industrial Market Structure at 387 (cited in note 30); see Arrow, Economic Welfare at 619-22 (cited in note 30) (arguing that if the problem of appropriability is ignored, firms in a competitive market will have a greater incentive to invent than would a monopolist because the competitive firm's incentive is equal to the full cost reduction on the competitive output, while the monopolist's incentive is diminished by the set-off of preinvention monopoly profits).

10 Richard Posner, Economic Analysis of Law 54 (Little, Brown, 2d ed 1977); Yoram Barzel, The Optimal Timing of Innovations, $50 \mathrm{Rev}$ Econ \& Stat 348 (1968).

1 Machlup, Subcomm on Patents, Study No 15 at 45-50 (cited in note 30) and sources cited therein; Plant, 1 Economica at 40-42 (cited in note 30 ).

${ }^{42}$ McGee, $9 \mathrm{~J} \mathrm{~L} \&$ Econ at 137 (cited in note 30); Plant, 1 Economica at 45-46 (cited in note 30 ).

13 Scherer, Industrial Market Structure at 392 (cited in note 30); Baxter, 76 Yale L J at 270 (cited in note 32); Machlup, Subcomm on Patents, Study No 15 at 64 (cited in note 30); Kahn, $30 \mathrm{Am}$ Econ Rev at 482 (cited in note 36); Plant, 1 Economica at 46 (cited in note 30 ). Edmund Kitch argues that this particular effect of the patent monopoly promotes efficiency in research. See notes 97-116 and accompanying text.

The essence of the argument that patents undermine the incentives of persons other than the patent holders to make improvements in patented inventions is that once an invention is patented, only the patent holder and her licensees are able to reap rewards in the market for research leading to further refinements in the invention, while in the absence of patents competitors would also stand to benefit from such research. This argument overlooks the fact that the value of the improvement to the patent holder and her licensees might still give other researchers an incentive to develop it. See text at note 118.
} 
tors of the patent holder to waste time and effort finding duplicative solutions to technological problems in order to avoid infringement. ${ }^{44}$

\section{Incentive to disclose.}

The incentive to disclose argument, which has been more popular with the courts than with commentators, rests on the premise that in the absence of patent protection inventors would keep their inventions secret in order to prevent competitors from exploiting them. ${ }^{45}$ Secrecy prevents the public from gaining the full benefit of new knowledge and leads to wasteful duplicative research. ${ }^{46}$

Economists have questioned whether patents in fact promote

44 Judicial opinions often cite the incentive to invent around patents as a positive benefit of the patent system, reasoning that inventing around patents requires further research and thus stimulates further progress. See, for example, Yarway Corp. $v$ Eur-Control USA, 775 F2d 268, 277 (Fed Cir 1985); State Indus. v A.O. Smith Corp., 751 F2d 1226, 1236 (Fed Cir 1985); Kimberly-Clark Corp. v Johnson \& Johnson, 745 F2d 1437 (Fed Cir 1984). See also John C. Stedman, Invention and Public Policy, 12 J L \& Contemp Probs 649, 662 (1947).

But some commentators argue that inventing around patents is socially wasteful in that it diverts resources from other productive uses to the task of finding redundant solutions to already solved problems. See, for example, Donald F. Turner, The Patent System and Competitive Policy, 44 NYU L Rev 449, 455 (1969); Machlup, Subcomm on Patents, Study No 15 at 51 (cited in note 30 ). Machlup argues that research to find duplicative solutions to problems is particularly wasteful when done by the holder of the patent on the first solution in order to prevent competitors from inventing around the patent. Id. See Bowman, Patent and Antitrust Law at 21-22 (cited in note 30) (arguing that inventing around patents is not necessarily socially wasteful if it leads to the development of superior products or processes, and that it is reasonable to assume that those who incur the costs of inventing around patents foresee inventing superior substitutes); Scherer, Industrial Market Structure at 386-87 (cited in note 30 ) (noting that although the pace of technological advance has probably been accelerated in some fields by efforts to invent around patented technologies, resources devoted to circumventing patents might otherwise be allocated to activities with "higher social incremental payoffs"); Martin J. Adelman, The Supreme Court, Market Structure and Innovation: Chakrabarty, Rohm and Haas, 27 Antitrust Bull 457, 464 (1982) (arguing that efforts to invent around patent are unlikely to occur unless competitor and patent holder have different views of cost of developing alternative technology and thus are unable to agree on royalty for use of patented technology that makes it uneconomic to develop an alternative).

15 Universal Oil Prods. Co. v Globe Oil \& Ref. Co., 322 US 471, 484 (1944); Grant v Raymond, 31 US 218, 247 (1832); Sinclair \& Carroll Co. v Interchemical Corp., 325 US 327, 331 (1945); Cross v Iizuka, 753 F2d 1040, 1046 (Fed Cir 1985); Flick-Reedy Corp. v HydroLine Mfg. Co., 351 F2d 546, 550-51 (7th Cir 1965); Bowman, Patent and Antitrust Law at 12-13 (cited in note 30); S.C. Gilfillan, The Root of Patents, or Squaring Patents by Their Roots, 31 J Pat Off Soc'y 611, 612 (1949) (deriding "disclosure incentive" as "minor motive" for granting patents and one falling "outside the root of patents").

40 Martin J. Adelman, Property Rights Theory and Patent-Antitrust: The Role of Compulsory Licensing, 52 NYU L Rev 977, 982 (1977). 
disclosure of inventions that would otherwise be kept secret. ${ }^{47} \mathrm{Se}$ crecy is not always a practical strategy for protection, ${ }^{48}$ and often secret technologies can eventually be uncovered through reverse engineering. ${ }^{49}$ Where long term secrecy is feasible, patent protection for a mere seventeen years might not be an attractive alternative. ${ }^{50}$ Moreover, any technology that can be exploited in secrecy by its inventor can probably also be exploited in secrecy by an infringer, making a patent on such an invention difficult to enforce. ${ }^{51}$ Finally, some people have questioned whether patent disclosures in fact convey enough information to be useful to the public. ${ }^{52}$ The proposition that patents promote disclosure of new inventions by rewarding those who disclose their inventions in patent applications is thus open to doubt on a number of grounds.

Nonetheless, it seems likely that the patent system at least facilitates disclosure by creating rights in inventions that survive disclosure. Secrecy makes it difficult for inventors to sell or license their inventions to others because it is difficult to persuade someone to pay for an idea without disclosing it, yet once the invention is disclosed, the inventor has nothing left to sell. ${ }^{53}$ The patent system solves this problem by permitting inventors to disclose their

67 See Scherer, Industrial Market Structure at 381 (cited in note 30); Machlup, Subcomm on Patents, Study No 15 at 32-33, 53, 76 (cited in note 30). See also Canada Dep't. of Consumer \& Corp. Affairs, Working Paper on Patent Law Revision 40-42 (1976) ("Canada Working Paper").

4s Secrecy is impractical when efficient exploitation of the invention requires communication to a large number of firms. See Bowman, Patent and Antitrust Law at 13 (cited in note 30 ).

19 Plant, 1 Economica at 44 (cited in note 30). See generally Paulik v Rizkalla, 760 F2d 1270,1276 (Fed Cir 1985) ("[I]t is a rare invention that cannot be deciphered more readily from its commercial embodiment than from the printed patent").

so Bowman, Patent and Antitrust Law at 13 (cited in note 30).

B1 Eisenberg, 97 Yale L J at 215 (cited in note 3).

${ }^{32}$ Critics of the patent system charge that patent applicants often deliberately withhold important information from patent specifications so that they may continue to protect their "know-how" through trade secrecy. See, for example, Brenner v Manson, 383 US 519, 533-34 (1966). See also Canada Working Paper, at 50-53 (cited in note 47); Machlup, Subcomm on Patents, Study No 15 at 32-33 (cited in note 30); William D. Nordhaus, Invention, Growth, and Welfare: A Theoretical Treatment of Technological Change 89 (MIT, 1969) ("It is well known that a firm tries not to disclose key parts of the invention in order to reduce the chance of imitation, thereby reducing the effective diffusion of knowledge"); S.C. Gilfillan, Invention and the Patent System 61 (GPO, 1964) ("The information disclosed in patents is often not enough, taken by itself, to be of much use to the receiver"); Barkev S. Sanders, Joseph Rossman, and L. James Harris, Attitudes of Assignees Toward Patented Inventions, 2 Pat, Trademark \& Copyright J Res \& Educ 465, 467-68 (Dec 1958) (estimating that about one-half of patented inventions cannot be used without supplementary knowhow).

ss See Arrow, Economic Welfare at 615 (cited in note 30 ). 
patented inventions to potential users without losing their exclusive rights. If persons receiving disclosure use patented inventions without permission, the patent holders may sue them for infringement. ${ }^{54}$

3. Implications for $\ddot{a}$ research exemption to the patent monopoly.

Neither the incentive to invent theory nor the incentive to disclose theory offers any clear guidance in formulating a research exemption from infringement liability. One source of difficulty is that the cases and literature elaborating these theories have focused primarily on commercial applications of new technology rather than on basic scientific research. Indeed, many of the commentators cited herein distinguish the development of inventions in applied technology from basic scientific research and explicitly exclude the latter from their analysis. ${ }^{55}$ It is thus unclear how far it is appropriate to extend these theories in analyzing the role of patents in research.

A more serious limitation, not limited to the specific question of whether to exempt research uses from infringement liability, is that neither of these theories supplies an answer to the empirical question of how much incentive is necessary for an optimal level of invention and disclosure. ${ }^{56}$ One might assume that, other things being equal, reducing the strength of patents would reduce incentives to make and disclose new inventions and that, conversely, increasing the strength of patents would increase incentives to make new inventions and to patent them in lieu of protecting them as trade secrets. But the magnitude of these effects is uncertain. Moreover, it is difficult to say whether the current level of incentives is too high or too low. ${ }^{57}$

Nor does either theory suggest a basis for distinguishing a re-

s4 Polanyi, 11 Rev of Econ Studies at 64 (cited in note 30). See also Edmund W. Kitch, The Nature and Function of the Patent System, $20 \mathrm{~J} \mathrm{~L} \mathrm{\&} \mathrm{Econ} \mathrm{265,} \mathrm{277-78} \mathrm{(1977)} \mathrm{(assert-}$ ing that patent law defines a framework of legal relations among firms to facilitate disclosure, licensing, etc).

${ }^{s s}$ See, for example, Nelson, $32 \mathrm{~J}$ Bus at 105 (cited in note 30); Machlup, Subcomm on Patents, Study No 15 at 1 (cited in note 30); Polanyi, 11 Rev of Econ Studies at 75 (cited in note 30 ).

${ }^{86}$ See generally Machlup, Subcomm on Patents, Study No 15 at 62-73 (cited in note 30) (discussing difficulties involved in analyzing impact on incentives of one-year change in patent term).

${ }^{87}$ Baxter, 76 Yale L J at 268-69 (cited in note 32); McGee, $9 \mathrm{~J} \mathrm{~L} \mathrm{\&} \mathrm{Econ} \mathrm{at} 136$ (cited in note 30$)$. 
search exemption from other ways of reducing the strength of patents, such as restricting the scope of patent rights or reducing the duration of the patent term. The incentive to invent and incentive to disclose arguments are analytical dead ends for those seeking to fine tune the patent laws. They offer no guidance in evaluating the relative merits of different packages of patent rights apart from suggesting a comparison, if this were possible, of the overall strength of the incentives the different packages create. Thus the question of whether to exempt research users from infringement liability is quickly reduced to the empirical question of whether doing so would undermine the strength of patent incentives to an undesirable degree.

There is considerable empirical evidence suggesting that technological change has been an extremely important source of economic growth over time, ${ }^{58}$ and that levels of invention are responsive to economic stimuli. ${ }^{59}$ But it does not necessarily follow that patent protection is necessary to preserve adequate economic incentives for invention and innovation.

Eric Schiff has compared the historical record of industrial development of countries with and without patent systems during the late nineteenth and early twentieth centuries, finding little evidence that the lack of a patent system hampered industrializa-

ss See, for example, Moses Abramovitz, Resource and Output Trends in the U.S. Since 1870, 46 Am Econ Rev 5 (1956) (Amer Econ Assoc Papers and Proceedings); Robert M. Solow, Technological Change and the Aggregate Production Function, $39 \mathrm{Rev}$ Econ \& Stat 312,320 (1957) (estimating that approximately 80 percent of the growth in nonfarm output per worker in the United States between 1909 and 1949 was attributable to technological change rather than increased capital intensity); Edward F. Denison, The Sources of Economic Growth in the United States and the Alternatives Before Us 271-72 (Brookings Inst, 1962) (estimating that 36 percent of the rise in output per worker between 1929 and 1957 was attributable to the advance of scientific and technological knowledge); Edward F. Denison, Accounting for United States Economic Growth, 1929-69 128 (Brookings Inst, 1974) (estimating that 27 percent of U.S. economic growth between 1929 and 1969 was attributable to advances in knowledge); Frederic M. Scherer, Inter-Industry Technology Flows and Productivity Growth, 64 Rev Econ \& Stat 627 (1982) (estimating that in the post-War era $R \& D$ has added to the rate of growth by about one percentage point per year, or about half of the annual rate of growth in productivity).

s9 See generally Jacob Schmookler, Invention and Economic Growth (Harvard, 1966) (finding strong correlation between level of invention as measured by patent statistics and level of investment in capital goods, with peaks and troughs in invention tending to precede rather than to follow peaks and troughs in investment, and concluding that patented inventions are made in response to rising demand in an industry); Edwin Mansfield, et al, Research and Innovation (cited in note 33) (showing correlation between research and development funds expended and expected success of a research project and profitability of its results, and showing that timing of research and development and innovation are responsive to profit expectations). 
tion. ${ }^{60}$ But the two countries he studied that did not have patent systems - the Netherlands and Switzerland-may have been free riding on domestic and foreign inventions that were stimulated by patent protection abroad. ${ }^{61}$ Other studies have attempted to determine, through interviews and questionnaires, the impact of patent incentives on research and development $(R \& D)$ decision making in firms. C.T. Taylor and Z.A. Silberston, in their study of the economic impact of the patent system in the United Kingdom, found that the importance of patent protection to the R\&D decision making of firms varied across industries. ${ }^{62}$ They found that patent protection had a strong influence on the willingness of pharmaceutical firms to invest in research and development, but had no more than a marginal impact on R\&D expenditures in the basic chemicals industry. ${ }^{63}$ In a similar study of U.S. firms, F.M. Scherer found that respondents did not consider patents to be particulary important in R\&D decision making-except when patent lawyers prepared the responses. ${ }^{64}$ Nonetheless, the authors of both studies interpreted their results to suggest that weakening patent protection by providing for compulsory licensing of patented inventions on reasonable terms would lead to greater reliance by firms on secrecy instead of patent protection. ${ }^{65}$

so Eric Schiff, Industrialization Without National Patents 34-41, 96-106 (Princeton, 1971). Schiff's study focuses on the experiences of the Netherlands, which abolished its patent system in 1869 and did not replace it until 1912, and Switzerland, which did not introduce a comprehensive patent system until 1907. Id at 14-15.

${ }^{61}$ Id at 23-24, 102-04. During the period under study, citizens of both Switzerland and the Netherlands were eligible for foreign patent protection under the national patent laws of other countries. Id at 21-23.

Schiff found a marked increase in the number of foreign patent applications filed by Dutch citizens after the Netherlands introduced its own patent system, which he interprets as evidence that the availability of patent protection in the Netherlands stimulated an increase in domestic inventive efforts. Id at 42-51. Scherer suggests a different interpretation of Schiff's data: the passage of a Dutch patent law may have made Dutch citizens more patent-conscious and induced the growth of patent law firms, leading to more patenting abroad of inventions that might have been made with or without patent protection. Frederic M. Scherer, The Economic Effects of Compulsory Licensing 36-37 (NYU, 1977).

${ }^{62}$ C.T. Taylor and Z.A. Silberston, The Economic Impact of the Patent System 331-50 (Cambridge, 1973).

${ }^{63}$ Attempting to explain this difference, they noted that research expenditures are higher relative to sales volume in the pharmaceutical industry than in the chemical industry, that there are more non-patent barriers to competition in the chemical industry, that patents provide stronger protection in the pharmaceutical field than in the chemical field because of the relative ease of inventing around chemical patents, and that secrecy is not practical in the pharmaceutical industry. Id at 332-36.

64 Scherer, Compulsory Licensing at 52-62 (cited in note 61).

${ }^{\mathrm{B}} \mathrm{Id}$ at 62; C.T. Taylor and Z.A. Silberston, Economic Impact at 210-13, 352 (cited in note 62). 
Another empirical approach to determining the adequacy of the current level of patent incentives is to measure the difference between private and social rates of return to investments in research and development. In case studies of seventeen industrial innovations, Edwin Mansfield and his colleagues found that the median estimated social rate of return to investment in R\&D was 56 percent, while the median private rate of return was about 25 percent. ${ }^{66}$ According to the study, "in about $30 \%$ of the cases, the private rate of return was so low that with the benefit of hindsight no firm would have invested in the innovation, but the social rate of return was so high that from society's standpoint the investment was entirely worthwhile." ${ }^{\text {"77 }}$ While the authors caution against drawing any inferences about the extent of underinvestment in research and development from their results, ${ }^{68}$ the data are certainly consistent with the view that the current level of incentives to make and disclose new inventions is if anything too low. Other studies have tentatively suggested that private rates of return from investments in research and development are significantly higher than returns available on other investments, ${ }^{69}$ offering further evidence that firms underinvest in research and development.

If one assumes that the level of incentives provided by an unqualified seventeen year patent monopoly is either optimal or too low, then it arguably follows that the use of a patented invention in research should only be exempt from infringement liability when it has no adverse impact on the patent holder's profits. ${ }^{70} \mathrm{~A}$ broader exemption would reduce the value of the patent monopoly and thereby reduce incentives to make and disclose new inventions. Without articulating this rationale, some courts seem to have taken approximately this position on the proper scope of the experimental use defense.

A few early cases that considered the experimental use defense stated that it should only be available when use of a patented in-

o6 Edwin Mansfield, et al, Social and Private Rates of Return from Industrial Innovations, 91 Q J Econ 221, 233-34 (1977).

67 Id at 235. The gap between social and private rates of return was larger for more important innovations and for innovations that could be imitated at small cost by competitors. Id at 237.

88 Id at 240.

"See, for example, Edwin Mansfield, Industrial Research and Technological Innovation $65-80$ (Norton, 1968).

${ }^{70}$ Alternatively, one might argue that the profitability of patents should be increased in some other manner, such as by lengthening the patent term, in order to compensate for any reduction in the value of patents from the introduction of an experimental use exemption. 
vention in research causes no "harm" to the patent holder. ${ }^{71}$ Limiting the defense in this way presents several problems. The noharm approach to experimental use seems to rest on the erroneous premise that research scientists who use patented inventions in purely non-commercial research, or in research that does not compete with the commercial interests of the patent holder, cause no "harm" to the patent holder. However, any unlicensed use of a patented invention harms the patent holder if the user would otherwise have paid a royalty for the use. The question of whether an unlicensed use has "harmed" the patent holder thus leads right back to the question of whether the user should have paid for a license. Ironically, a no-harm limitation would seem to confine the defense to situations in which it is unnecessary, since patent holders are unlikely to bring infringement actions unless they feel harmed by the defendants' conduct. Moreover, the fact that a defendant's use of a patented invention has caused no harm to the plaintiff is not ordinarily a defense to a patent infringement claim. ${ }^{72}$

The 1890 Robinson patent treatise, which the courts have continued to cite in experimental use cases into the 1980 's, ${ }^{73}$ offers a slightly more refined version of the no-harm standard, asserting that the use of an invention should not constitute infringement unless it is "hostile to the interest of the patentee ... represented by the emoluments which he does or might receive from the practice of the invention by himself or others." "74 According to this view of "experimental use," where the use of an invention in research produces "no pecuniary result" the patent holder has not lost any of her "emoluments" and her interests are not antagonized. On the other hand, if the user conducts experiments with a view to adapting the invention to a business purpose, the use constitutes infringement, and "even experimental uses will be sometimes enjoined though no injury may have resulted." Consistent with this approach, the courts have generally refused to recognize an experimental use exemption for research performed by commercial

${ }^{71}$ See, for example, Byam v Bullard, 4 F Cases 934, 935 (D Mass 1852); Albright, 1 F Cases at 323.

${ }^{72}$ Roche Products, 733 F2d at 861; see generally Stickle v Heublein, Inc., 716 F2d 1550 (Fed Cir 1983). See also Eisenberg, 97 Yale L J at 221 n 231 (cited in note 3).

${ }^{73}$ See Roche Products, 733 F2d at 862; RCA v Andrea, 15 F Supp 685, 686-87; Ruth $v$ Stearns-Roger Mfg. Co., 13 F Supp 697, 713 (D Colo 1935).

${ }^{74}$ William C. Robinson, The Law of Patents for Useful Inventions § 898 at 55-56 (Little, Brown, 1890).

${ }^{75} \mathrm{Id}$. 


\section{firms. ${ }^{76}$}

This definition of experimental use refines the no-harm standard by drawing a distinction between commercial and noncommercial research. While this distinction might appear to be an appropriate place to draw the line between research uses that should trigger infringement liability and those that should be protected from liability by an experimental use exemption, the difference between commercial and noncommercial research in fact often has little to do with the financial interests of patent holders.

An isolated use of a patented invention in purely academic research with no commercial implications might have little impact on the profitability of the patent, assuming that in the absence of an exemption the researcher would forego use of the invention rather than obtaining a license. But for inventions with significant markets among researchers, such as patented laboratory techniques and other research tools, ${ }^{77}$ exempting even purely academic researchers from the patent monopoly could deprive patent holders of a portion of the monopoly profits they might otherwise expect to earn and thereby reduce incentives to make and disclose such inventions in the future. Research users are ordinary consumers of such an invention. To exempt such users from infringement liability would plainly undermine the interest of the patent holder in "the emoluments which he might receive from the practice of the invention by others." tion for patents suggests that researchers, like other consumers, should be required to pay royalties to the developers of inventions that are useful to them in order to maintain a level of incentives that is adequate to justify developing such inventions.

An incentives analysis also argues against an exemption for research users who are potential competitors of the patent holder rather than potential customers. For example, consider the case of

76 See cases cited in note 8.

77 Of course, in the case of a product invention such as a patented laboratory machine, anyone who buys the product after it was made under authorization of the patent holder has an implied license to use the invention embodied in the product. See $U$. S. $v$ Univis Lens Co., 316 US 241, 249 (1942) ("[T]he authorized sale of an article which is capable of use only in practicing the patent is a relinquishment of the patent monopoly with respect to the article sold."). The same principle applies to an authorized sale of items especially adapted for use in a patented process-the purchaser has an implied license to use the items to perform the patented process. See, for example, Met-Coil Sys. Corp. v Korners Unlimited, Inc. 803 F2d 684 (Fed Cir 1986). The problem of unauthorized use addressed in the text arises only when the research user bypasses the patent holder entirely in making or using the invention.

${ }^{78}$ See note 74 and accompanying text. 
a researcher who is using a patented invention to develop alternative means of solving the same problem. ${ }^{79} \mathrm{~A}$ research exemption in this context would not only deprive the patent holder of the royalties that this particular user might otherwise pay, but also threatens ultimately to cut short the effective duration of the patent holder's monopoly if the user succeeds in developing a competing technology that can be used without infringing the patent claims. Such research is plainly hostile to the financial interests of the patent holder and reduces the expected profitability of the patent, suggesting that an exemption from infringement liability in this context would reduce patent incentives.

One might object that the patent laws should not protect patent owners from the "loss of emoluments" arising from technological obsolescence of the patented invention. Otherwise, the patent laws would give the patent holder a financial incentive to block the development of new technologies. Thus, an exemption from infringement liability may be necessary in order to be sure that technological progress occurs. Such an exemption is consistent with the intuition of some courts that "inventing around" patents is socially beneficial. ${ }^{80}$

But the rationale for such an exemption is in tension with the incentives justification for patents. Permitting the unlicensed use of patented inventions for the purpose of inventing around patents would appear to reduce the value of patents by shortening the term of effective commercial monopoly, thereby reducing incentives to make patentable inventions in the first place.

Even when research users are neither potential customers nor potential competitors of the patent holder, the incentives justification for patents does not supply an argument for a research exemption. At most, it suggests that such an exemption will be harmless so long as it does not affect the overall profitability of the patent.

\section{Incentive to Innovate and the Prospect Theory}

Although the courts have relied primarily on the incentive to invent and incentive to disclose arguments in support of the patent system, ${ }^{81}$ commentators have offered the additional argument that

70 See text accompanying note 222 .

${ }^{80}$ See note 44.

81 A rare possible exception is the concurring opinion of Judge Frank in Picard $v$ United Aircraft Corp., 128 F2d 632 (2d Cir 1942), in which he states: "The controversy between the defenders and assailants of our patent system may be about a false issue-the 
a patent monopoly is necessary to induce firms to invest in "innovation"-i.e., putting existing inventions to practical use. ${ }^{82}$ Even after an invention has been made, considerable further investment is often necessary before it is ready for commercial exploitation. Further research and development may be needed to establish the commercial feasibility of the invention and to bring it into large scale production. Use of the invention may call for the construction of new plant and equipment. A new product invention may require further refinements to suit the tastes of consumers, as well as promotion and advertising expenditures to persuade consumers to buy it. These additional investments may dwarf the initial research expenditures in making the invention. ${ }^{83}$ The protection of a patent monopoly enhances the likelihood that a firm will be willing to undertake these investments.

Like the incentive to invent and incentive to disclose theories, the incentive to innovate theory holds that the patent system achieves its objectives by offering monopoly profits as a lure to promote desired behavior. But it differs from these other theories with respect to the time frame in which the incentive matters. The incentive to invent and incentive to disclose theories are concerned with incentives that operate before a patent issues. These theories assume that the patent monopoly has already served its social function of promoting invention and disclosure as soon as the patent issues, and that enforcement of the patent thereafter is simply the regrettable price that society must pay in order to live up to its end of the bargain. ${ }^{84}$ Reducing the strength of existing patents

stimulus to invention. The real issue may be the stimulus to investment." Id at 643 . This statement suggests a view of the patent system as promoting innovation as well as invention. See also SCM v Xerox, 645 F2d 1195, 1206 n 9 (2d Cir 1981).

${ }^{82}$ See, for example, Scherer, Industrial Market Structure at 381 (cited in note 30); Scherer, Invention and Innovation in the Watt-Boulton Steam Engine Venture, 6 Tech \& Culture 165 (1965); Machlup, Subcomm on Patents, Study No 15 at 36-38, 56 (cited in note 30); Stedman, $12 \mathrm{~J} \mathrm{~L} \&$ Contemp Probs at 653 (cited in note 44).

ss Edwin Mansfield, et al, The Production and Application of New Industrial Technology (Norton, 1977); Scherer, Industrial Market Structure at 381 (cited in note 30) (noting that development outlays constitute more than three fourths of all industrial $R \& D$ expenditures); John Jewkes, David Sawers, and Richard Stillerman, The Sources of Invention 21217 (MacMillan, 2d ed 1969). See also Frederic M. Scherer, Innovation and Growth: Schumpeterian Perspectives 3-7 (MIT, 1984) (explaining that firms are more willing to invest large sums in development than in invention because of the unpredictability of initial technical breakthroughs).

st As Machlup explains:

If one accepts the theory that patent protection has the social function of serving as an incentive for inventive activity, one accepts, by implication, that the beneficial effects of this incentive system must flow, not from existing patents, but from the hope for future profits from future patents; this hope may induce people to undertake certain 
would thus presumably offer short run social benefits by increasing the use of already patented inventions, although in the long run it would reduce incentives to make and disclose new inventions. By contrast, the incentive to innovate theory gives existing patents an ongoing role in preserving the incentives of patent holders to invest in development during the patent term. Reducing the strength of existing patent monopolies might thus have the effect of undermining incentives to put existing technologies into use. ${ }^{85}$

\section{The Schumpeterian Theory.}

The thesis that monopolies are conducive to innovation is generally associated with the work of Joseph Schumpeter on economic development. ${ }^{86}$ While Schumpeter does not focus exclusively on either technological innovations or the patent system, his analysis suggests how patent monopolies might promote technological innovation. ${ }^{87} \mathrm{He}$ emphatically distinguishes innovation from invention, noting that invention itself produces "no economically relevant effect at all." Innovation, on the other hand, brings about incessant

risky investments and useful activities-to wit, financing and arranging industrial research-which they might not undertake otherwise. . . [E]xisting patents impose a burden on society, a burden which it has decided to carry in order to hold out to people the chance of obtaining future profits from future patents on future inventions. Machlup, Subcomm on Patents, Study No 15 at 55 (cited in note 30).

ss While Machlup notes the emergence of "incentive to innovate" arguments and acknowledges that existing patents would play an ongoing role in stimulating post-patent innovation as opposed to pre-patent invention, he does not analyze these arguments beyond stating that they require demonstrating "that innovations based on patentable inventions are socially more desirable than other innovations, and that the free-enterprise system would not, without monopoly incentives, generate investment opportunities to an adequate extent." Id at 56. He also suggests, without elaboration, that the use of patents to promote innovation rather than invention might not be properly subsumed in the Constitutional goal of promoting "the Progress of Science and useful Arts." Id.

${ }^{86}$ Joseph Schumpeter, Capitalism, Socialism and Democracy 81-110 (Harper \& Row, 3d ed 1950); Joseph Schumpeter, 1 Business Cycles 84-192 (McGraw Hill, 1939); Joseph Schumpeter, The Theory of Economic Development 61-94 (Transaction reprint, Redvers Opie trans 1983). See also, generally, Scherer, Schumpeterian Perspectives, (cited in note 83); Morton I. Kamien and Nancy L. Schwartz, Market Structure and Innovation (Cambridge, 1982); Vernon W. Ruttan, Usher and Schumpeter on Invention, Innovation, and Technological Change, 73 Q J Econ 596 (1959); Carolyn S. Solo, Innovation in the Capitalist Process: A Critique of the Schumpeterian Theory, 65 Q J Econ 417 (1951).

${ }^{87}$ Schumpeter defines innovation broadly to include not only putting new technological inventions into practice, but also carrying out any new combination of productive resources that amounts to "the setting up of a new production function." Schumpeter, 1 Business Cycles at 87 (cited in note 86). In Schumpeter's usage the term innovation includes the development of new consumer goods, new methods of production, new markets, and new forms of industrial organization. Id at 84; Schumpeter, Capitalism, Socialism \& Democracy at $82-83$ (cited in note 86 ).

${ }^{88}$ Schumpeter, 1 Business Cycles at 84 (cited in note 86). See also Schumpeter, The 
revolutionary changes in the economic system through what Schumpeter calls "a process of creative destruction." cess, new firms continually arise to carry out new innovations, driving out old firms that provide obsolete goods and services. Competition from new commodities and new technologies is far more significant in this model than price competition among firms offering similar goods and services. ${ }^{90}$

Schumpeter argues that in a dynamic model of the capitalist system, monopoly conditions may promote innovation and growth more effectively than competition. ${ }^{91} \mathrm{He}$ bases this view primarily on "the tritest common sense," although he also notes as a matter of casual observation that economic advances are more frequently traced to big business than to firms in atomistically competitive industries. ${ }^{98} \mathrm{He}$ reasons that in the rapidly changing conditions of a capitalist economy, investment in innovation requires some sort of hedge against losses. ${ }^{94}$ Protection from competition also allows firms "to gain the time and space for further developments." Finally, and perhaps most important, the prospect of earning more than an ordinary return permits innovators to secure the financial backing of capitalists and to bid productive resources away from their current uses. ${ }^{96} \mathrm{~A}$ monopoly position secured through patent protection thus may increase rather than restrict the use of known technologies by facilitating the commer-

Theory of Economic Development at 88-89 (cited in note 86) ("As long as they are not carried into practice, inventions are economically irrelevant. And to carry any improvement into effect is a task entirely different from the inventing of it.").

"Schumpeter, Capitalism, Socialism \& Democracy at 83 (cited in note 86).

90 Id at 84. Competition arising from innovation "strikes not at the margins of the profits and the outputs of the existing firms but at their foundations and their very lives." Id.

91 Id at 87-106.

92 Id at 91.

"2 Id at 82. For other perspectives, see generally Arrow, Economic Welfare (cited in note 30) (arguing that incentive to innovate should be greater for competitive firms than for monopolists); Henry Villard, Competition, Oligopoly and Research, $66 \mathrm{~J}$ Pol Econ 483 (1958) (arguing that "competitive oligopoly," characterized by a small number of big firms, promotes research better than either pure competition or monopoly).

Subsequent empirical studies to test Schumpeter's impression that monopoly conditions are more conducive to innovation than competition have been inconclusive. Scherer, Schumpeterian Perspectives at 169-255 and sources cited therein (cited in note 83); Kamien and Schwartz, Market Structure at 49-104 and sources cited therein (cited in note 86); Scherer, Industrial Market Structure at 363-64 and sources cited therein (cited in note 30).

or Schumpeter, Capitalism, Socialism \& Democracy at 88 (cited in note 86) (arguing that monopoly profits may represent in part a charge to consumers for the imputed cost of self-insurance against future losses).

${ }^{85}$ Id at 89.

* Schumpeter, The Theory of Economic Development at 67-74 (cited in note 86). 
cial introduction of such technologies by innovating firms.

The Schumpeterian theory, while supplying a basis for believing that patents serve some ongoing function even after inventions have been made, nonetheless offers little guidance in assessing the proper role of patents in subsequent research. To the extent that an experimental use exemption facilitates the development of alternative technologies to compete with a patented invention, it would shorten the expected duration of the patent holder's effective monopoly, thereby reducing incentives to invest in the commercial development of the existing patented invention. Moreover, the loss of royalties that might otherwise be collectible from researchers would reduce the value of patent monopolies, thereby weakening incentives to innovate. But in the absence of some way of measuring the magnitude of these effects, the Schumpeterian perspective soon leads to the same analytical dead end as the incentive to invent and incentive to disclose theories: its policy implications turn on empirical questions without clear answers.

\section{The Prospect Theory.}

Edmund Kitch offers a more elaborate analysis of the role of patents in post-invention innovation in what he calls the "prospect theory" of patent protection. ${ }^{97}$ According to this theory, the patent system promotes efficiency in the allocation of resources to the development of existing inventions by awarding exclusive, publicly recorded ownership in new technological "prospects" shortly after their discovery. ${ }^{88}$ The term "prospect theory" highlights an analogy between the functions of patent monopolies and awards of exclusive mineral claims in government owned lands in the American West. ${ }^{89}$

The prospect theory offers a justification for patents that is in keeping with broader theories of property rights elaborated by Harold Demsetz ${ }^{100}$ and Richard Posner. ${ }^{101}$ These commentators ar-

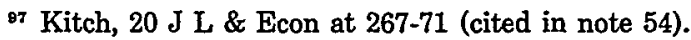

s8 Id at 268 .

- The analogy between patents and mineral claims was foreshadowed by George Frost in a footnote in a 1946 article. George Frost, Legal Incidents of Non-Use of Patented Inventions Reconsidered, 14 Geo Wash L Rev 273, 279 n 24 (1946) ("An interesting analogy may be drawn between the law relating to patents for inventions and the mining law, an analogy which emphasizes the fact that patents are only one of the many situations where an exclusive grant is provided to encourage effort and capital investment.").

${ }^{100}$ Harold Demsetz, Toward a Theory of Property Rights, 57 Am Econ Rev 347 (1967) (Am Econ Assoc Papers \& Proceedings).

101 Posner, Economic Analysis of the Law at 27-31 (cited in note 40). 
gue that private property rights promote greater efficiency in the use of resources than communal ownership because individuals can be expected to exploit communally owned resources too quickly in order to appropriate the resources for themselves before other community members deplete them. The result will be an exhaustion of resources by individuals in the present, with the costs to be borne by the community as a whole in the future. Private ownership avoids this problem by placing property owners in a position to realize the full costs as well as the benefits of exploitation, thereby internalizing what would be external costs in a system of communal ownership.

The analogy between patents and other types of property ${ }^{102}$ is not immediately apparent because inventions that can be used to an unlimited extent without exhaustion do not seem to present the same problems of scarcity and depletion as tangible resources. Kitch clarifies the analogy by noting that while information may be used without exhausting it, resources available to use information are scarce, and property rights in inventions can improve the efficiency with which these resources are managed. ${ }^{103}$

Kitch contends that patents promote efficiency in the use of resources to develop patented inventions in part by putting patent owners in a position to coordinate subsequent research and development efforts. ${ }^{104}$ Since the owner of a patent has the exclusive right to exploit the technology defined in the patent claims, no one else is likely to invest in developing this technology without first making arrangements with the patent owner; otherwise, the subsequent researchers might ultimately be unable to benefit from their own investment in development for lack of a license to the underlying patented technology. The patent owner is thus in a position

102 While judicial decisions often speak of patent rights as a species of "property," economists studying the patent system for the most part have not drawn on property rights theory. Indeed, Fritz Machlup argues that the characterization of patents as creating "property rights" in inventions reflects confusion as to the difference between "property" and "monopoly." Machlup, Subcomm on Patents, Study No 15 at 53-54 (cited in note 30). Machlup and Penrose trace this confusion to a deliberate "political ruse" advanced by nineteenth century advocates of the patent system in order to claim for their cause the respectable connotations of the word "property" in place of the less favorable connotations of the word "privilege." Machlup and Penrose, $10 \mathrm{~J}$ Econ Hist at 16-17 (cited in note 27).

${ }^{103}$ Kitch, $20 \mathrm{~J} \mathrm{~L} \mathrm{\&} \mathrm{Econ} \mathrm{at} \mathrm{275-76} \mathrm{(cited} \mathrm{in} \mathrm{note} \mathrm{54).}$

${ }^{104}$ Id at 276. Kitch also asserts that patents promote efficiency in the development of technological prospects by preserving the incentives of patent holders to develop their inventions without fear that the results of these efforts will be appropriated by competitors and by allowing patent holders to disclose their technological achievements to other firms without losing their exclusive rights, thereby facilitating the transfer of technology among firms and reducing the amount of duplicative research efforts. Id at 276-79. 
to cause researchers to share information and thereby avoid duplicative research efforts. In the absence of a patent, different investigators might try independently to develop the same invention in secrecy, each working without the benefit of the knowledge gained through the efforts of the others. Exclusive rights in technological prospects thus promote efficiency in research after the patent issues by putting the patent holder in a position to monitor and control such research.

Kitch finds support for the thesis that patent rights play a significant role in the ongoing development of patented inventions in two features of the patent system. ${ }^{105}$ First, the patent statute authorizes and promotes patent protection at an early stage in the development of new inventions, ${ }^{106}$ making it likely that further research will remain to be done in order to develop an invention during the term of the patent. ${ }^{107}$ According to Kitch, inventions are commonly patented long before it becomes commercially feasible to exploit them. ${ }^{108}$ The inventor who delays filing a patent application while continuing to develop the invention may lose the right to patent protection entirely if in the interim the inventor makes a public use of the invention ${ }^{109}$ or begins to exploit it commercially in secrecy; ${ }^{110}$ if the invention is described in the literature or used

105 These features are analyzed at length in id at $267-71$, and only briefly reviewed in text herein.

${ }^{108}$ In order to obtain a patent, an applicant need only show that the invention works-i.e., that it is capable of performing some useful function. The applicant need not show that the invention works better than other means of accomplishing the same purpose, nor even that it works well. All that is necessary is a written disclosure of the invention sufficient to enable someone skilled in the field to reduce the invention to practice-i.e., to make and use it. 35 USC $\S \S 102(\mathrm{~g}), 112$ (1982). The applicant does not have to describe every possible embodiment of the invention, although $\S 112$ does require disclosure of the "best mode" of practicing the invention known to the inventor at the time the patent application is filed.

${ }^{107}$ Kitch, $20 \mathrm{~J} \mathrm{~L} \mathrm{\&} \mathrm{Econ} \mathrm{at} \mathrm{269-71} \mathrm{(cited} \mathrm{in} \mathrm{note} \mathrm{54).}$

${ }^{108}$ Empirical evidence contradicts Kitch on this point. Barkev Sanders, in a study of assigned patents issued in 1938,1948 , and 1952, found that of the estimated 10 percent of patented inventions ever put to commercial use, about 40 percent were first put to use before the patent application was filed, about 50 percent were first put to use while the application was pending, and only about 10 percent were first put to use after issuance of the patent. Barkev Sanders, Speedy Entry of Patented Inventions into Commercial Use, 6 Pat, Trademark \& Copyright J of Research \& Educ 87 (1962). See also Scherer, Compulsory Licensing at 9-10 and sources cited therein (cited in note 61) (indicating that the making of a patentable invention accompanies or follows commercial development more frequently than it precedes a lengthy period of subsequent development).

10935 USC § 102(b) (1982); Egbert v Lippmann, 104 US 333 (1881).

110 See generally Pennock v Dialogue, 27 US (2 Pet) 1 (1829); Metallizing Engineering Co. $v$ Kenyon Bearing \& Auto Parts Co., 153 F2d 516 (2d Cir 1946). 
by others; ${ }^{111}$ if intervening progress in the field makes the invention obvious; ${ }^{12}$ or if a competitor files an earlier patent application on the same invention. ${ }^{113}$

Second, Kitch asserts that the patent monopoly is generally not limited to the primitive version of the invention described in the patent application, but extends to subsequent refinements as well.114 Subsequent improved versions of the invention falling within the scope of the patent claims and newly discovered uses for the invention, although the product of further research by others, will still be subject to the control of the patent holder until the patent expires. ${ }^{116}$ The patent holder will therefore stand to benefit from subsequent research to improve the invention, while other researchers will have little incentive to pursue further research on a patented invention without first arranging for a license to the underlying patent. ${ }^{116}$ Kitch argues that taken together, these features of the patent system tend to promote control over subsequent research on patented inventions by patent holders and their licensees, and that such control promotes efficiency.

The prospect theory finds no direct support in the language of judicial decisions and has been criticized by economists. ${ }^{17}$ Nonetheless, those who believe that the prospect theory identifies an important function of the patent system might argue that patent

${ }^{111} 35$ USC \& 102(b) (1982).

11235 USC \& 103 (1982).

11 Although in the U.S. patent system patent priority is awarded to the first inventor rather than to the first to file a patent application, the date of the patent application is presumed to be the same as the applicant's date of invention unless the inventor is able to prove an earlier invention date. See 35 USC § 102(g) (1982); Lacotte $v$ Thomas, 758 F2d 611 (Fed Cir 1985).

${ }^{114} \mathrm{Kitch}, 20 \mathrm{~J} \mathrm{~L} \mathrm{\&} \mathrm{Econ} \mathrm{at} \mathrm{268-69} \mathrm{(cited} \mathrm{in} \mathrm{note} \mathrm{54).} \mathrm{As} \mathrm{an} \mathrm{empirical} \mathrm{matter,} \mathrm{this}$ assertion is also subject to doubt. The scope of patent claims will often have to be quite narrow in order to distinguish the patented invention from the prior art. See generally Robert P. Merges, Commercial Success and Patent Standards: Economic Perspectives on Innovation, $76 \mathrm{Cal}$ L Rev 803, 840-41 (1988) and sources cited therein.

11 The subsequent inventor might be entitled to a patent on her improvement or new use of the earlier invention, but would not be able to exploit this patent without the permission of the holder of the patent on the underlying invention. The patent on the improvement or new use would enable the subsequent inventor to prevent the underlying patent holder from using this later invention. Thus no one could use the improvement without the permission of both patent holders. See, for example, Marconi Wireless Tel. Co. $v$ DeForest Radio Tel. \& Tel. Co., 236 F 942 (S D NY 1916), affd, 243 F 560 (2d Cir 1917).

118 See note 43 and accompanying text.

${ }^{117}$ See, for example, Frederic M. Scherer, Industrial Market Structure and Economic Performance 447 n 30 (Rand McNally, 2d ed 1980) (stating that Kitch's views seem "little influenced by any concern for reality"); Roger L. Beck, The Prospect Theory of the Patent System and Unproductive Competition, 5 Res L \& Econ 193 (1983) (noting that contrary to Kitch's assumptions, patents do not protect future developments). 
holders should be able to use their exclusive rights to control the use of their inventions in subsequent research. An exemption from infringement liability for those who use patented inventions in research could interfere with the prospect function by preventing patent holders from monitoring and coordinating subsequent research efforts within the patent prospect. Subsequent researchers who do not need the patent holder's permission to proceed with their research might work in secrecy, duplicating each other's efforts without knowing what their predecessors have already learned.

In some situations, patent holders may not need a legal right to stop others from doing research to improve their inventions in order for patents to perform the prospect function. So long as patent holders can prevent the ultimate commercial exploitation of improved versions of their inventions, one might expect that unlicensed researchers would have little incentive to undertake improvement efforts without first entering into agreements with patent holders even if they did not yet need a license at the research stage. Without such agreements, they might find at the end of their research that they were unable to exploit the results of their own efforts because the patent holder was unwilling to grant them a license to use the underlying invention. ${ }^{118}$

Some subsequent researchers might find it worthwhile to improve a patented invention even without a license if the improvement itself were patentable. The inventor of the improvement could sell licenses to use the improvement to the holder of the patent on the underlying invention and her licensees. Moreover, holding exclusive rights in the improvement might enhance the bargaining position of the subsequent inventor in negotiating for a license to the underlying invention. Thus, while the right to prevent ultimate commercial exploitation of an invention might sometimes be enough to put patent holders in a position to coordinate subsequent research efforts to improve their inventions, it seems likely that in some cases unauthorized (and uncoordinated) research will proceed unless patent holders have the right to enjoin the use of their inventions in research. In such cases an experimental use exemption arguably undermines the prospect function, thus interfering with the efficient development of a patent prospect. 


\section{Summary}

Although judicial decisions have long recognized that the use of patented inventions in research should be exempt from infringement liability, theoretical justifications for the patent laws offered by the courts and commentators do not supply a clear rationale for such an exemption. The courts generally justify the award of patents as providing an incentive to make and disclose new inventions. This justification says nothing about what level of incentives is optimal for achieving these goals, nor does it afford a basis for excluding research users from the categories of users who must pay patent holders for access to their inventions. Nonetheless, it lends a superficial coherence to the suggestion of some courts that research uses of patented inventions can safely be exempted from liability because they cause no harm or loss of profits to the patent owner. ${ }^{119}$ If one assumes that the level of patent incentives provided by an unqualified seventeen year monopoly, without an experimental use exemption, is either optimal or too low, then it arguably follows that any such exemption should only apply to research uses that have no impact on this level of incentives. This reasoning would seem to argue against an experimental use exemption for research users who are either potential customers or potential competitors of the patent holder.

The work of several commentators, most notably Joseph Schumpeter, suggests that patent monopolies might promote technological innovation - the practical development of existing inventions. Unfortunately, like the incentive to invent and incentive to disclose theories, the policy implications of the incentive to innovate theory turn on empirical questions without clear answers.

The prospect theory seems to argue against an experimental use exemption for subsequent research in the field of the patented invention. This theory focuses on efficiency in subsequent research rather than on promoting research before the patent issues, holding that patents promote efficiency by permitting patent owners to monitor and control subsequent research within the scope of a patented technological prospect. It is not clear in all cases that a patent must confer the right to exclude researchers from using the invention in order to achieve these efficiency benefits. Nonetheless,

110 The coherence is superficial because the no-harm analysis fails to address the question of whether, in the absence of an exemption, the research user might have paid a royalty to the patent owner. Moreover, the analysis ignores the possibility that subsequent research users of a patented invention will destroy the value of the patent monopoly by developing alternative technologies. See text at notes 71-80. 
it seems likely that at least in some cases an exemption from infringement liability for research users of patented inventions could operate at cross purposes with the prospect function by permitting wasteful duplicative research.

With this background, we can now consider countervailing arguments in favor of free access to prior discoveries as a means of promoting scientific progress emerging from the sociology, history, and philosophy of science literature.

\section{The Case for Free Access to Scientific Discoveries}

\section{A. Communal Ownership of Discoveries as a Scientific Ideal}

The idea of enforcing of exclusive rights in new discoveries against researchers fundamentally conflicts with traditional scientific norms calling for free dedication of new knowledge to the scientific community. ${ }^{120}$ Robert Merton describes this scientific norm of "communism" as follows:

The substantive findings of science are a product of social collaboration and are assigned to the community. They constitute a common heritage in which the equity of the individual producer is severely limited. ... The scientist's claim to "his" intellectual "property" is limited to that of recognition and esteem. . . . 121

Merton explains the norm of communism primarily in functional terms, arguing that it derives from the scientific community's insti-

120 See Merton, Normative Structure at 270 (cited in note 2); Barber, Science and the Social Order at 90-93 (cited in note 2); Storer, Social System of Science at 79 (cited in note 3); Hagstrom, The Scientific Community at 12-23 (cited in note 3).

121 Merton, Normative Structure at 273 (cited in note 2). Merton identifies "communism" as one of four interrelated norms of science, the others being universalism, disinterestedness, and organized skepticism. "Universalism" means that the veracity of claimed observations is to be determined on the basis of impersonal criteria without regard to the identity of the scientist who makes the observation. Id at 270-73. "Disinterestedness" means that scientists should seek new knowledge for its own sake rather than seeking to further their own interests. Id at 275-77. "Organized skepticism" means that the scientific community should subject the claims and beliefs of its members to empirical scrutiny before accepting them as true. Id at 277-78.

According to Merton, scientists violate the norm of communism whenever they restrict access to their discoveries-even if they do so for the sole purpose of compelling "payment" in the form of proper acknowledgement of their contributions:

Once he has made his contribution, the scientist no longer has exclusive rights of access to it. It becomes part of the public domain of science. Nor has he the right of regulating its use by others by withholding it unless it is acknowledged as his.

Robert K. Merton, Priorities in Scientific Discovery, in Merton, The Sociology of Science at 286,294 (cited in note 2). 
tutional goal of "the extension of certified knowledge."122 The reward system of science reinforces this norm by impelling scientists to contribute new knowledge to the community in order to earn recognition for priority of discovery. ${ }^{123}$

Bernard Barber identifies the same value, under the less politically charged label of "communality," as one of the "ideals of the social organization of science." "24 For Barber, the ideal of communality has both a moral dimension and a functional dimension. In moral terms, it calls upon scientists who have benefitted in their research from access to prior discoveries of others to repay the debt by contributing their own discoveries to the scientific community as a whole. ${ }^{125}$ In functional terms, it ensures that all scientists will have access to the ideas, materials, and collegial interaction necessary to proceed with their own work. ${ }^{126}$

Both Merton and Barber remark upon the contrast between the communal character of ownership in new scientific discoveries and the exclusivity of private property rights in a capitalist economy. ${ }^{127}$ At a functional level, the contradiction between scientific communism/communality and the grant of exclusive rights in new discoveries under the patent system reflects divergent perspectives on how best to promote scientific progress. The patent laws rest on the premise that granting exclusive rights in discoveries will pro-

122 Merton, Normative Structure at 270 (cited in note 2). Merton also identifies a moral dimension to the norms of science, noting that although they derive from functional considerations they are binding on scientists in part "because they are believed right and good." Id.

123 Id at 273.

124 Barber, Science and the Social Order at 90-91 (cited in note 2). Barber's scientific "ideals" parallel Merton's scientific norms (see note 121) with the substitution of "individualism" for "organized skepticism" (Barber, Science and the Social Order at 65 (cited in note $2)$ ), and the addition of "rationality" and "emotional neutrality." Id at 86-89.

123 Id at 91 "'The man who takes from science according to his needs has the moral obligation to publish any new discoveries he builds upon the goods that the community has lent him.").

${ }^{126}$ Id. ("Secrecy ... deprives [scientists] of the necessary materials of their own work. It also eliminates what we shall see is essential to all scientific innovation, namely, the informal discussion among scientists of new work and new ideas.").

${ }^{127}$ Barber notes that in its ideal of communality the scientific community departs from the dominant moral values of a liberal society: "Where liberal society as a whole values private property rights in scarce goods, in science such rights are reduced to the absolute minimum of credit for priority of discovery." Id.

Merton sees the scientific norm of communism as "incompatible with the definition of technology as 'private property' in a capitalistic economy," noting that the inconsistency arises from "discrepancies in the conception of intellectual property." Merton, Normative Structure at 275 (cited in note 2). In other words, the scientist's "intellectual property" is not a right to exclude others from using the invention, but merely a right to acknowledgement and recognition for dedicating a new discovery to the community. 
mote progress; the normative authority of scientific communism/ communality derives at least in part from the assumption that this same goal will be better served by granting free access to such discoveries. $^{128}$

\section{B. Functions of Free Access to Discoveries}

Sociologists of science often take it for granted that free access to prior discoveries promotes scientific progress without bothering to explain why this is so. Many commentators have observed that scientists often depart from communitarian ideals in practice, ${ }^{129}$ but for the most part they have not challenged the social desirability of compliance with these ideals as a means of advancing science. ${ }^{130}$ Although most writers have not directly addressed the question of how free access to prior discoveries facilitates scientific progress, the literature in the sociology, history, and philosophy of science nonetheless sheds some light on this question.

\section{Scrutiny of research claims.}

One benefit of free access to scientific discoveries that features prominently in functionalist accounts of scientific norms is that access permits other scientists to scrutinize the claims of prior researchers. This provides a mechanism for decentralized social control within the scientific community. ${ }^{131}$

${ }^{128}$ See, for example, Barber, Science and the Social Order at 152 (cited in note 2) (asserting that university scientists oppose patenting their discoveries because scientific communality "is functionally necessary ... for otherwise parts of scientific theory would be removed from the public domain and thereby the advancement of science would be hindered."); see Storer, Social System of Science at 83-101 (cited in note 3) (arguing that scientists subscribe to the Mertonian norms of science primarily because of their importance for the continued and just allocation of "competent response" by professional colleagues to the contributions of individual scientists).

${ }^{120}$ See, for example, William Broad and Nicholas Wade, Betrayers of the Truth 78-79 (Simon \& Schuster, 1982); Ravetz, Scientific Knowledge and its Social Problems at 311-12 (cited in note 2); Theodore D. Sterling, Analysis and Reanalysis of Shared Scientific Data, 495 Annals of Am Acad Pd Soc Sci 49, 56-59 (1988) and sources cited therein; Michael Mulkay, Sociology of Science in the West, 28 Current Soc 1, 43-64 (1980) and sources cited therein; Nico Stehr, The Ethos of Science Revisited, in Jerry Gaston, ed, The Sociology of Science 172 (Jossey-Bass, 1978) and sources cited therein; Harriet Zuckerman, Deviant Behavior and Social Control in Science, in Edward Sagarin, ed, Deviance and Social Change 87, 102-04 (Sage, 1977). See also Eisenberg, 97 Yale L J at 182-83 n 17, 197-205 (cited in note 3).

${ }^{130}$ But also see Ian I. Mitroff, The Subjective Side of Science 73-79 (Elsevier, 1974); Ian I. Mitroff, Norms and Counter-Norms in a Select Group of the Apollo Moon Scientists: A Case Study of the Ambivalence of Scientists, 39 Am Soc Rev 579, 593-94 (1974) (discussed in notes 200-202 and accompanying text).

${ }^{311}$ See, for example, Merton, Normative Structure at 276 (cited in note 2); Storer, So- 
Although free access to prior research results theoretically permits attempts at replication and thus supplies a safeguard against fraud, error, or self-deception in the presentation of research claims, the effectiveness of this system of social control is open to question. Merton, writing in 1942, proclaimed the "virtual absence of fraud in the annals of science," attributing this remarkable record to "rigorous policing" ensured by "the public and testable character of science."132 More recent commentators have challenged the accuracy of Merton's claims in light of increasing reports of fraud in science, ${ }^{133}$ suggesting that there are significant limits to the mechanisms of the scientific community for ensuring effective scrutiny of research results.

One obvious limit arises from departures by scientists from the idealized communitarian norms described by Merton and Barber. The scientific community cannot scrutinize claimed discoveries that are not made available for replication. In practice, scientists often fail to publish their research results in replicable form and refuse to share their data or essential research materials with interested investigators even after publication. ${ }^{134}$ Even when results are published in replicable form or otherwise made subject to

cial System of Science at 82-83 (cited in note 3); Hagstrom, The Scientific Community at 956 (cited in note 3); Zuckerman, in Deviance and Social Change at 90-98 (cited in note 129).

132 Merton, Normative Structure at 276 (cited in note 2).

13s See, for example, Fraud in Biomedical Research: Hearings Before the Subcomm on Investigations and Oversight of the House Comm on Science and Technology, 97th Cong, 1st Sess (1981); AAAS-ABA National Conference of Lawyers and Scientists, Project on Scientific Fraud and Misconduct: Report on Workshop Number One (1988); Broad and Wade, Betrayers of the Truth (cited in note 129); Deena Weinstein, Fraud in Science, 59 Soc Sci Q 639 (1979).

13 See Broad and Wade, Betrayers of Truth at 76, 78-79 (cited in note 129); Sterling, 495 Annals at 56-59 (cited in note 129); Eisenberg, 97 Yale L J at 204 (cited in note 3); Stephen J. Ceci and Elaine Walker, Private Archives and Public Needs, 38 Am Psychologist 414, 415-18 (1983).

The reasons for these departures from communitarian norms are not difficult to surmise. Scrutiny of one's research claims could potentially result in the disclosure of bias, carelessness, or even outright fraud. Storer, Social System of Science at 128-29 (cited in note 3); Sterling, 495 Annals at 59 (cited in note 129). Or, the scrutinizer may simply disagree with the prior researcher's interpretation of data, leading to conflict and potential loss of esteem in the scientific community. Id at 58-59. For a recent example of a dispute over the interpretation of data leading to conflict and controversy in the scientific community, see Barbara J. Culliton, A Bitter Battle Over Error, 240 Science 1720 (1988); Barbara J. Culliton, A Bitter Battle Over Error (II), 241 Science 18 (1988); Philip M. Boffey, Nobel Winner Is Caught Up in a Dispute over Study, NY Times C1 (April 12, 1988). Moreover, sharing one's research discoveries could allow competitors to gain an advantage in subsequent research, diluting opportunities to earn additional recognition for future discoveries emanating from the earlier results. Storer, Social System of Science at 129-31 (cited in note 3); Sterling, 495 Annals at 57-58 (cited in note 129); Eisenberg, 97 Yale L J at 204-07 (cited in note 3 ). 
effective scrutiny, actual efforts at replication are rare. ${ }^{135}$ The high degree of specialization in some research fields reduces the number of investigators capable of replicating any given piece of research. ${ }^{138}$ Even among specialists, the degree of reproducibility of research results varies from one discipline to the next, depending on such factors as the precision of measurements attainable in the present state of knowledge in the discipline and whether data is gathered through observation of a complex and changing field or through experimentation under controlled conditions. ${ }^{137}$

Beyond these problems of feasibility is a problem of motivation. Replication consumes time and resources and is rarely worth the effort. ${ }^{138}$ It is difficult to obtain funding or to earn recognition in the scientific community for experiments aimed at replicating someone else's work, and such experiments are unlikely to lead to publication whatever their outcome. ${ }^{138}$ Scientific rewards accrue to those who publish original research, not to those who merely repeat what somebody else has already done. ${ }^{140}$

Another reason why scientists might fail to check the prior research results of their colleagues through replication is that they may be predisposed to accept without challenge research results that confirm prevailing theories. The expectation that scientists will attempt to replicate each other's published research results assumes that scientists adopt a skeptical attitude toward received wisdom and that the scientific enterprise subjects hypotheses to

135 Broad and Wade, Betrayers of the Truth at 76-77 (cited in note 129); see generally Zuckerman, in Deviance and Social Change at 94 (cited in note 129) (asserting that the extent of actual replication varies from one scientific field to the next).

1ss Id at 94.

${ }^{137}$ Storer, Social System of Science at 117-18 (cited in note 3); Zuckerman, in Deviance and Social Change at 93 (cited in note 129).

${ }^{138}$ Broad and Wade, Betrayers of the Truth at 76 (cited in note 129). Repeating an experiment that was done in another laboratory may require obtaining equipment and materials and mastering new techniques. Scientists generally do not have the time and resources to replicate even all of the prior work on which their own current research depends. Weinstein, 59 Soc Sci Q at 648 (cited in note 133).

${ }^{139}$ See id at 646 (reporting private correspondence from an anonymous researcher who indicated that a journal that had published an original study was unwilling to consider the researcher's refutation of the study for publication, and that another journal agreed to publish the refutation only after it was revised to delete any questions raised about the integrity of the original researcher's findings); See also Theodore D. Sterling, Publication Decisions and Their Possible Effects on Inferences Drawn from Tests of Significance or Vice Versa, $54 \mathrm{~J}$ Am Stat Assoc 30 (1959) (reporting that not one paper published in three major psychology journals in 1955 and in another in 1956 replicated previous work).

16 Hagstrom, The Scientific Community at 69 (cited in note 3); Patricia K. Woolf, Deception in Scientific Research, in AAAS-ABA National Conference of Lawyers and Scientists at 37,61 (cited in note 133). 
rigorous testing. As Merton explains:

The organization of science operates as a system of institutionalized vigilance, involving competitive cooperation. It affords both commitment and reward for finding where others have erred or have stopped before tracking down the implications of their results or have passed over in their work what is there to be seen by the fresh eye of another. In such a system, scientists are at the ready to pick apart and appraise each new claim to knowledge. ${ }^{141}$

This sociologist's conception of an eternally vigilant scientific community is consistent with the image of science underlying the philosophical tradition of logical empiricism. For example, Karl Popper argues that the criterion of demarcation that distinguishes science from nonscience is that scientific theories are subject to "falsification" by comparing theory-based predictions with the results of empirical tests. ${ }^{142}$ According to Popper, science advances through ever more rigorous efforts of scientists to prove prevailing theories wrong. ${ }^{143}$

Thomas Kuhn challenges this view of science, arguing that scientists generally aim to confirm prevailing theories rather than to falsify them. ${ }^{144}$ According to Kuhn, fields of research develop in stages marked by the influence of distinct "paradigms," or exemplary solutions to specific research problems, that serve as models for researchers working in the field. ${ }^{145}$ Such paradigms, and the un-

141 Robert K. Merton, Behavior Patterns of Scientists, in Merton, ed, The Sociology of Science at 325, 339 (cited in note 2).

${ }^{162}$ Karl Popper, The Logic of Scientific Discovery 34-42 (Hutchinson, English ed 1959). Popper explains that a scientific theory can never be verified, since subsequent observations might always prove it wrong. At best, a theory may be corroborated for the time being by experiments that yield results consistent with its predictions. Id at 32-34, 251-81. Thus, scientific research never leads to the discovery of general statements of regularities that may be accepted as "true." Id at 44-48.

143 Id at 278-81.

14 See Thomas Kuhn, The Structure of Scientific Revolutions (Chicago, $2 \mathrm{~d}$ ed 1970). For a comparison of the views of Kuhn and Popper, see Thomas Kuhn, Logic of Discovery or Psychology of Research?, in Imre Lakatos and Alan Musgrave, eds, Criticism and the Growth of Knowledge 1-3 (Cambridge, 1970), reprinted in Thomas Kuhn, The Essential Tension 266 (Chicago, 1977); and Karl Popper, Normal Science and its Dangers, in Criticism and the Growth of Knowledge at 51.

${ }^{145} \mathrm{Kuhn}$, Structure at viii (cited in note 144) ("I take [paradigms] to be universally recognized scientific achievements that for a time provide model problems and solutions to a community of practitioners."). An example of a "paradigm" in this sense is Ptolemy's computations of planetary position. Id at 23. Elsewhere in The Structure of Scientific Revolutions, Kuhn uses the term "paradigm" more loosely, at times embracing the entire set of beliefs and methodological and instrumental commitments shared by a community of scien- 
derlying theories and assumptions on which they are based, form the core of what Kuhn calls a "normal science" research tradition. ${ }^{146}$ Most scientists spend most of their time engaged in normal science, attempting to solve esoteric problems posed by the prevailing traditions and theories in their fields. ${ }^{147} \mathrm{Kuhn}$ asserts that the aim of these scientists is not to test or falsify prevailing theories, but rather to reconcile empirical observations with theories to which they are already intellectually committed. ${ }^{148}$ During periods of normal science, scientists are unlikely to challenge research claims that corroborate theories underlying the prevailing research tradition.

Scrutiny of prior claims may be more likely, and free access to prior research thus more important, during those rare periods of crisis in a field of research preceding what Kuhn calls "scientific revolution."148 According to Kuhn, normal science leads inexorably to such periods of crisis by generating anomalous results that cannot be explained in terms of the prevailing theory. ${ }^{150}$ Eventually the community loses confidence in its paradigms, and scientists then exhibit the sort of critical skepticism that is traditionally attributed to them as they assess the relative explanatory powers of

tists working in the same field. See Margaret Masterman, The Nature of a Paradigm, in Criticism and the Growth of Knowledge at 59, 61-66 (cited in note 144) (identifying twentyone separate senses in which Kuhn uses the term "paradigm"); Compare Kuhn, Structure at 174, 175 (cited in note 144) (postscript, 1969) (acknowledging that he uses the term "paradigm" in two separate senses: first, to signify "the entire constellation of beliefs, values, techniques, and so on shared by the members of a given community"; and second, to signify "one sort of element in that constellation, the concrete puzzle-solutions which, employed as models or examples, can replace explicit rules as a basis for the solution of the remaining puzzles of normal science"); see also Thomas Kuhn, Second Thoughts on Paradigms, in The Essential Tension at 293 (cited in note 144).

146 Kuhn, Structure at 23-51 (cited in note 144).

147 Id at 23-24.

348 Id at 146-47.

${ }^{149}$ Id at 52-91. Free access to prior research discoveries may also be important during the early stages of research in a field before a widely accepted paradigm has emerged, when competing schools offer competing theories and challenge each other's assumptions, hypotheses, and observations. Id at 10-22. Access to applied research discoveries may be particularly important to the progress of pre-paradigm research. Kuhn argues that the lack of a generally accepted paradigm impedes systematic fact gathering in pre-paradigm science, restricting analysis to data that are readily accessible. Id at 15 . The prior discoveries of applied scientists may be especially important as a supplement to the limited knowledge generated by basic scientists before they have a paradigm to guide them in their research. The practical problems addressed by applied research may in effect substitute for a scientific paradigm in systematizing fact gathering by identifying appropriate areas of inquiry. Id at 16.

150 Id at 52-65. 
competing new theories. ${ }^{151}$ The crisis ultimately comes to an end when a new paradigm emerges that commands the allegiance of a significant group of practitioners and forms the basis of a new normal science tradition. ${ }^{\mathbf{1 6 2}}$ Kuhn notes that the scientists whose achievements form the basis for new paradigms are almost always either very young or very new to the field, and thus less committed by prior practice to its normal science tradition. ${ }^{153}$ In the meantime, adherents of the old paradigm continue to defend it and seek to elaborate upon it in ways that reconcile apparently anomalous empirical observations with the predictions of the paradigmbased theory. ${ }^{154}$

During these periods of "extraordinary science," when new theories compete with old theories for the allegiance of a scientific community, free access to prior discoveries may be essential in order to put the proponents of new theories in a position to challenge their predecessors and offer alternative explanations for previous observations. If scientists were able to limit access to their discoveries, they might make them available only to those who shared their intellectual commitments, making it difficult for proponents of new theories to perform the experiments necessary in order to offer new interpretations of research results. ${ }^{185}$ Free access to prior discoveries may thus be critical in allowing newcomers to the field to challenge the achievements of more established figures.

Free access to prior research discoveries thus serves the interest of the scientific community in checking the validity of research results by facilitating scrutiny of scientists' claims. Critical scru-

181 Id at 77-91.

152 Id at $84-86,150-59$.

15s Id at 90 . For a related analysis, see Michael J. Mulkay, The Social Process of Innovation: A Study in the Sociology of Science 34-45 (Macmillan, 1972) (arguing that intellectual migration, followed by modified application of imported techniques from another field, is more common than radical redefinition of paradigms from within a field).

136 Kuhn, Structure at 77-80. See also Mitroff, The Subjective Side of Science at 61-73 (cited in note 130) (noting that scientists often remain committed to theories in the face of what others regard as falsifying evidence and suggesting that such strong intellectual commitments may be functional for science); and Bernard Barber, Resistance by Scientists to Scientific Discovery, 134 Science 596 (1961) (arguing that scientists resist new discoveries because of conflict with substantive concepts, methodological conceptions, or religious ideas; or because of patterns of social interaction based on professional standing, specialization, conflict among "schools," and seniority).

${ }^{18 s}$ See generally Diana Crane, Invisible Colleges: Diffusion of Knowledge in Scientific Communities 41-65 (Chicago, 1972) (noting that informal communications among scientists tend to be dominated by a small number of productive scientists who play a key role in the dissemination of information and exercise considerable influence over theoretical commitments and future directions of research in their fields). 
tiny of research claims may be far less common than the popular image of science would suggest. Nonetheless, some such scrutiny undoubtedly occurs. Harriet Zuckerman suggests that scrutiny of prior research claims is most likely when the results are either anomalous or particularly significant for subsequent research. ${ }^{156}$ While this pattern of limited replication may allow some false research claims to enter the scientific literature without objection, Zuckerman argues that focusing scrutiny on particularly significant research results is an efficient way of allocating the scarce resources available to the scientific community for replicating prior work. ${ }^{157}$

Anomalous research results may be dismissed as research failures and overlooked by scientists committed to a prevailing paradigm during periods of normal science, and then reexamined later during the crisis preceding a scientific revolution. Significant nonanomalous research results may be accepted without objection so long as they confirm the predictions of prevailing theories in the field, and then called into question when their deficiencies are exposed as an unintended by-product of efforts to extend them. ${ }^{158}$ Either way, free access to prior discoveries ensures that the community will be able to scrutinize research results when it needs to use them or when it is ready to pay attention to them.

Some scrutiny of research results might occur by permission or license even without free access to prior discoveries. Some scientists might want their colleagues to scrutinize their results in order to confirm their discoveries and obtain recognition. ${ }^{159}$ Nonetheless, there are good reasons why the scientific community might consider "licensed access" a poor substitute for free access as a means of providing for scrutiny of research claims. First, to the extent that scrutiny of research claims is potentially antagonistic to the

${ }^{186}$ Zuckerman, Deviance and Social Change at 94-95 (cited in note 129).

157 Id at 95-96.

${ }^{168}$ Id at 93. See also Broad and Wade, Betrayers of the Truth at 77 (cited in note 129).

160 Norman Storer explains compliance with the norm of communality in terms of individual motivation rather than social function, noting that scientists contribute their discoveries to the scientific community in order to obtain "competent response" from professional colleagues. Storer, Social System of Science at 83-84 (cited in note 3). According to Storer, the desire for response that motivates scientists is more than simply a desire for the practical benefits that go with favorable recognition, such as fame, prizes, research funding, and professional advancement. Recognition of one's achievements by other scientists is an integral part of the discovery process, providing essential confirmation and validation for scientists' cognitive evaluations of their discoveries. Id at 20-21, 66-73. See also Hagstrom, The Scientific Community at 12-23 (cited in note 3) (asserting that scientists contribute their discoveries to the scientific community in order to receive recognition). 
interests of the prior researcher, requiring a license from that researcher is bound to compromise the credibility and effectiveness of the process. Researchers might tend to submit their results to the scrutiny only of like-minded colleagues who are predisposed to accept their claims and who will not challenge their fundamental assumptions. Moreover, the limited data available on the willingness of scientists to share their research results with other investigators suggests that many scientists in fact choose to withhold from the scientific community the means of scrutinizing their research claims. ${ }^{160}$ Finally, subsequent researchers will rarely be interested in replicating prior research, even when they are free to do so, unless they seek either to falsify it or to extend it in their own work. Thus scrutiny is most likely to occur, and most important for the progress of science, when it conflicts with the interests of the prior researcher. In these circumstances free access may be necessary to ensure that effective scrutiny may proceed.

\section{Facilitating new research.}

In addition to permitting scrutiny of research claims, free access promotes scientific progress by permitting other scientists to use prior discoveries in subsequent research. Functionalist accounts of scientific norms stress the cumulative nature of scientific discovery, noting that new discoveries build upon prior discoveries. ${ }^{161}$ Scientists have been proclaiming their indebtedness to the research of their predecessors for centuries-a sentiment that is vividly pictured in Isaac Newton's famous epigram: "If I have seen farther, it is by standing on the shoulders of giants."162

It may be that most if not all new discoveries build upon prior discoveries, and that scientists therefore need to use prior discoveries in order to advance the state of scientific knowledge. But it

${ }^{160}$ See note 134 and sources cited therein.

161 See, for example, Merton, in The Sociology of Science at 273, 346-52 (cited in note 2) ("The substantive findings of science are a product of social collaboration and are assigned to the community."); and Barber, Science and the Social Order at 197, 198-206 (cited in note 2) (". . . inventions and discoveries are in their very essence accumulations of previously existing elements, accumulations in which a degree of novelty may be present but may also be very small when the past is considered"); Gilfillan, The Sociology of Invention at 5-13 (cited in note 36); Ogburn, Social Change at 73-118 (cited in note 36); William F. Ogburn and Dorothy Thomas, Are Inventions Inevitable? A Note on Social Evolution, 37 Pol Sci Q 83 (1922). See also Kuhn, Structure at 52, 92 (cited in note 44) (asserting that while normal science is cumulative, scientific revolutions are non-cumulative transitions between incompatible and incommensurable world views).

102 For an exhaustive and entertaining account of the origins of this epigram, see Robert K. Merton, On the Shoulders of Giants: A Shandean Postscript (Free Press, 1965). 
does not necessarily follow that subsequent researchers need to enjoy free access to such discoveries; they might instead obtain licenses from prior researchers. In other words, contractual arrangements among scientists holding exclusive rights in discoveries might substitute for communal ownership as a means of regulating the use of prior discoveries in subsequent research.

The interests of the subsequent researcher (and of the scientific community as a whole) are less clearly at odds with the interests of the earlier researcher in the case of subsequent efforts to extend prior research than they are in the case of subsequent efforts to scrutinize prior research claims. Although prior researchers still stand to lose professional status if subsequent research calls into question the validity of their claims, they also stand to gain further recognition and status if their prior discoveries prove important to future discoveries. ${ }^{163}$ One might therefore expect scientists to be eager to extend licenses to those who would use their discoveries in subsequent research.

Nonetheless, there are a number of reasons why access to prior discoveries that is contingent on obtaining a license from the original discoverer might be a less satisfactory means of promoting scientific progress than free access to such discoveries.

The most obvious reason is that it is cheaper and easier to obtain free access to prior discoveries than it is to obtain licenses from prior researchers. Even assuming that most prior researchers would be willing, once consulted, to allow subsequent researchers to use their discoveries free of charge, it would be costly and burdensome for scientists to negotiate for licenses with each of the prior researchers whose work contributes to their own. ${ }^{164}$ Moreover, since research often leads down unexpected paths, it may be difficult to foresee just which prior discoveries will prove useful in a research project. ${ }^{168}$ Interrupting an ongoing research project to obtain a license to use a prior discovery that has unexpectedly proved relevant to the inquiry could cause wasteful delays. These

${ }^{183}$ Hagstrom, The Scientific Community at 23-28 (cited in note 3); Ravetz, Scientific Knowledge and its Social Problems at 246-47 (cited in note 2).

164 See generally Wendy J. Gordon, Fair Use as Market Failure: A Structural and Economic Analysis of the Betamax Case and its Predecessors, 82 Colum L Rev 1600 (1983) (arguing that the fair use privilege in copyright law serves in part to exempt from infringement liability socially desirable uses of copyrighted works that could not be achieved through consensual agreements because of "market failure" for reasons such as prohibitive transaction costs).

185 This factor could also make it difficult to agree on the value of access to a particular discovery in negotiating a license at the outset of a research project. 
transaction costs alone could add up to a significant burden for researchers.

Free access also spares subsequent researchers the cost of paying royalties to their predecessors for the use of their discoveries. To the extent that prior researchers might otherwise charge such royalties, free access in effect provides a subsidy for subsequent research. ${ }^{166}$ Research subsidies may be especially appropriate for basic research that generates substantial public benefits yet cannot pay its own way in the market. ${ }^{167}$ Research is a costly and uncertain enterprise, and it often yields unexpected benefits to those who have not paid for it. ${ }^{168}$ The argument for subsidy may be less compelling when extended to research sponsored by private companies in the expectation of earning a profit, or to applied research the results of which may be effectively monopolized through patent protection or secrecy. But even if a subsidy is appropriate, it does not necessarily follow that prior researchers should bear the burden of this subsidy rather than society as a whole. It might be fairer and more efficient (ignoring the transaction costs outlined above) for the government to subsidize research in amounts sufficient to allow researchers to pay for access to the prior discoveries they need to use in their research. On the other hand, considerations of fairness might argue for placing this burden on prior researchers, given that in all likelihood they themselves benefitted from the free availability of earlier research results in making their own discoveries. ${ }^{169}$ Researchers who themselves benefitted from access to the discoveries of scientists who came before them might fairly be called upon to make similar contributions to the efforts of scientists who come after them. ${ }^{170}$

Free access may also be necessary in order to override the interest of prior researchers in keeping their discoveries away from research competitors. ${ }^{171}$ Scientists may want to carve out a domain of exclusivity in subsequent research for themselves and their col-

${ }^{188}$ Congress may have been motivated in part by the purpose of subsidizing research in enacting specific exemptions from patent infringement liability for the experimental use of inventions in fields of research dominated by federal funding, such as agriculture and atomic energy. See note 6.

${ }^{167}$ See Nelson, $67 \mathrm{~J}$ Pol Econ at 304-06 (cited in note 33).

1 iss Id at 302-04.

${ }^{160}$ This argument is, of course, somewhat circular: absent a prevailing rule of free access, there would be no reason to presume that researchers had benefitted from free access to the prior discoveries of others. Nonetheless, a significant amount of accumulated knowledge has always been freely available to both basic and applied scientists.

170 Barber, Science and the Social Order at 91 (cited in note 2).

171 See Eisenberg, 97 Yale L J at 197-98, 203-05 (cited in note 3). 
laborators in order to improve their odds of being first to make future discoveries. They may see other researchers working on similar problems as competitors who threaten to divert future recognition, research grants, and even commercial intellectual property rights in the output of research using the prior discovery. ${ }^{172}$

Finally, free access allows subsequent researchers to bypass the theoretical perspectives of their predecessors, thereby promoting the simultaneous pursuit of diverse and possibly inconsistent theoretical approaches to future inquiry. Scientists often hold strong intellectual commitments to particular ideas and theories that dominate their choices of research problems, interpretations of research results, and reactions to the work of other scientists. ${ }^{173}$ Such commitments are at the heart of Kuhn's "normal science."174 Ian Mitroff has documented this phenomenon in interviews with a group of forty-two scientists involved in the Apollo lunar missions. ${ }^{175}$ Mitroff's interviewees suggest a number of reasons why strong commitinents to particular viewpoints or theories even in the face of contradictory evidence might play a beneficial role in science. Commitment serves to motivate scientists and enhances the visibility of their viewpoints. ${ }^{176}$ It also makes it more likely that someone will identify supporting data and present the arguments in favor of a theory and that the theory will not suffer a "premature death" for lack of an advocate. ${ }^{177}$

Whatever the beneficial effects of intellectual commitments among scientists, such commitments can also work to suppress the emergence of new theories and thus ultimately to retard scientific progress. Paul Feyerabend argues that a proliferation of theories

172 Storer, Social System of Science at 129-31 (cited in note 3). For a recent example of an academic scientist withholding a potentially important discovery from research competitors, see Leslie Roberts, Race for Cystic Fibrosis Gene Nears End, 240 Science 282 (1988).

${ }^{173}$ See Mitroff, The Subjective Side of Science at 61-73 (cited in note 130); Kuhn, Structure at 24, 35, 40-41, 64-65, 77-80, 100-01, 150-52 (cited in note 144); Mulkay, The Social Process of Innovation at 9-17 (cited in note 153); Mitroff, $39 \mathrm{Am}$ Soc Rev at 585-91 (cited in note 130); and Stephen G. Brush, Should the History of Science Be Rated X?, 183 Science 1164 (1974). See also Michael J. Mulkay, Some Aspects of Cultural Growth in the Natural Sciences, 36 Soc Research 22, 31-39 (1969) (arguing that the body of established knowledge within a field influences scientists more than the social norms identified by Newton).

174 See notes 144-148 and accompanying text.

${ }^{178}$ Mitroff, The Subjective Side of Science (cited in note 130); and Mitroff, $39 \mathrm{Am}$ Soc Rev 579 (cited in note 130). The scientists interviewed unanimously indicated that the popular notion of the objective, emotionally disinterested scientist was naive. Mitroff, $39 \mathrm{Am}$ Soc Rev at 587.

${ }^{178}$ Id at 588.

177 Id at $588-89$. 
through scientific "anarchy" is more conducive to improving knowledge than "the determined application of a preferred ideology." 178 Feyerabend acknowledges that a certain amount of tenacity in commitment to a theory is desirable because theories may eventually be improved in a manner that accommodates initial difficulties and because experimental results are not always reliable. ${ }^{178}$ Rather than arguing against such tenacity, Feyerabend suggests that the growth of knowledge will be better served by "the active interplay of various tenaciously held views" than by the dominance of a single view as depicted by Kuhn in his discussion of normal science. ${ }^{180}$

Free access to prior discoveries may be necessary to ensure such a proliferation of viewpoints. If scientists are in a position to control who gets access to their discoveries, they might be inclined to favor a narrow range of researchers who share their commitments and to withhold their discoveries from scientists with different perspectives. Informal networks of communication among scientists may reinforce the intellectual commitments of leading scientists in a field, with established scientists choosing as collaborators those who share their basic viewpoints and resisting the revolutionary ideas of newcomers. Allowing earlier researchers to exercise such control over the course of subsequent research might thereby prolong the influence of prevailing theories and stifle creativity and originality. Free access to scientific discoveries thus promotes scientific progress by permitting widespread use of prior discoveries in subsequent research by scientists with different intellectual commitments and perspectives.

\section{Individualism versus coordination in research.}

Implicit in the foregoing discussion is the idea that free access promotes scientific progress by fostering individualism and independence in research. Traditional scientific norms hold that individual scientists should be free to select their own research problems, methods, and techniques and decide for themselves whether their research results and the results of other scientists

${ }^{278}$ Paul Feyerabend, Against Method: Outline of an Anarchistic Theory of Knowledge 37-53 (NLB, 1975). Feyerabend argues that consideration of alternative theories may be necessary in order to find a perspective from which it is possible to observe facts that demonstrate the limitations of the theory under analysis. Id at 42-43.

279 Paul Feyerabend, Consolations for the Specialist, in Lakatos and Musgrave, eds, Criticism and the Growth of Knowledge at 197, 204 (cited in note 144).

${ }^{180}$ Id at 201-09. 
are valid or invalid. ${ }^{181}$ These norms are particularly strong in academic science, where they are fortified by traditions of academic freedom. ${ }^{182}$ Industrial scientists generally have less freedom in their choice of research problems and work under closer supervision than academic researchers. ${ }^{183}$ But even in industry, research scientists often enjoy considerable professional autonomy within broadly defined areas of interest to the firm, especially when they perform basic research. ${ }^{184}$

The independence of scientists in the day to day conduct of research promotes progress by enabling scientists to exploit their expertise fully and to make use of new information as they acquire it in the course of their investigations, without needing to comply with instructions or justify their activities to supervisors. ${ }^{185}$ Coordination or central planning of research weakens the initiative of researchers and substitutes the judgment of the research coordinator for that of the individuals who are actually immersed in the details of the research. This can be a major problem for industrial research. ${ }^{188}$

${ }^{181}$ See Barber, Science and the Social Order at 65 (cited in note 2). Barber explains: [S]cience rejects the imposition of any truth by organized and especially by non-scientific authority. The canons of validity for scientific knowledge are also individualistic: they are vested not in any formal organization but in the individual consciences and judgments of scientists who are, for this function, only informally organized. Some of the resentment which scientists feel against so-called "planning" in science . . . derives from their individualistic fear that formally organized authority will be substituted for the informal judgments of peers in the control of science.

Id. See also Hagstrom, The Scientific Community at 105 (cited in note 3). Michael Mulkay argues that this functionalist account of the role of individualism in scientific progress has its origins in ideological claims used by scientists in efforts to obtain public support for science while avoiding outside interference with their work. Michael J. Mulkay, Norms and Ideology in Science, 15 Soc Sci Information 637, 648-50 (1976).

${ }^{182}$ See generally Rebecca S. Eisenberg, Academic Freedom and Academic Values in Sponsored Research, 66 Tex L Rev 1363, 1364-74 (1988) and sources cited therein.

${ }^{183}$ Hagstrom, The Scientific Community at 107-09 (cited in note 3); Kornhauser, Scientists in Industry at 16-82 (cited in note 3); and Barber, Science and the Social Order at $167-68$ (cited in note 2).

184 Kornhauser, Scientists in Industry at 25-33, 64-65 (cited in note 3); Nelson, Science and Invention, at 570-77 (cited in note 4) (evaluating the research policy of Bell Telephone Laboratories).

${ }^{185}$ Hagstrom, The Scientific Community at 107-08 (cited in note 3).

${ }^{186}$ As William Kornhauser observes: "Bureaucratic control . . . considerably weakens professional initiative and incentive, and therefore creativity and innovation. Bureaucratic organization is not conducive to the search for new ideas and applications, nor is it likely to encourage or exploit serendipity in research." Kornhauser, Scientists in Industry at 44 (cited in note 3). Joseph Ben-David's comparative studies of the growth of science in different societies offer empirical support for the related thesis that centralized organization of academic institutions hinders scientific progress, while a loose and competitive structure promotes progress. Joseph Ben-David, Scientific Productivity and Academic Organization 
Discussions of academic freedom have traditionally emphasized the importance of protecting professional researchers from the exercise of authority by non-scientists. ${ }^{187}$ But interference by scientific peers also compromises individualism in science and violates scientific norms. ${ }^{188}$ Free access to prior discoveries removes an obstacle to individualism by allowing scientists to proceed with their research plans without having to obtain the approval of prior researchers whose discoveries they need to use.

Michael Polanyi argues that "independent initiatives" by competing scientists working with knowledge of each other's achievements assures the most efficient possible organization of scientific research, and that any effort to coordinate or control the work of scientists can only impede progress. ${ }^{189}$ So long as all scientists are aware of the work of the others, they will take this work into account in formulating and adjusting their own research efforts without any need for imposed coordination. Polanyi likens this system of "coordination by mutual adjustment of independent initiatives" to what happens when a group of persons jointly fits together the pieces of a large jigsaw puzzle. ${ }^{190}$ Each person, working within sight of the others, will focus on a particular segment of the puzzle and watch out for opportunities that arise as each piece of the puzzle falls into place. If one person attempts to organize the group, its joint effectiveness will be reduced to that of the single person directing the enterprise. The same, he asserts, is true for science:

So long as each scientist keeps making the best contribution of which he is capable, and on which no one could improve (except by abandoning the problem of his own choice and thus causing an overall loss to the advancement of science), we may affirm that the pursuit of science by independent selfcoordinated initiatives assures the most efficient possible organization of scientific progress. . . . [A]ny authority which would undertake to direct the work of the scientist centrally would bring the progress of science virtually to a standstill. ${ }^{191}$

in Nineteenth Century Medicine, 25 Am Soc Rev 828 (1960). See also Joseph Ben-David, The Scientist's Role in Society (Prentice-Hall, 1971).

${ }^{187}$ See generally Eisenberg, 66 Tex L Rev at 1365-67 (cited in note 182) and sources cited therein.

${ }_{18 s}$ Hagstrom, The Scientific Community at 106 (cited in note 2).

${ }^{189}$ Michael Polanyi, The Republic of Science: Its Political and Economic Theory, 1 Minerva 54, 56 (1962).

190 Id at 55.

191 Id at 56. 
This argument for independence among scientists explicitly posits that each scientist is aware of what the others are doing. The efficiency of independent research efforts is less apparent when, in the absence of coordination, scientists would work in secrecy without knowledge of each other's progress. Scientists working in secrecy cannot adjust their activities in response to the efforts of the others and might therefore be more likely to duplicate each other's work or otherwise waste their time.

By relieving scientists of the need to obtain permission from their predecessors to use their discoveries in subsequent research, free access makes it easier for scientists to work in secrecy. Conventional accounts of scientific norms stress the importance of open disclosure while broadly condemning secrecy as inimical to scientific progress. ${ }^{182}$ Yet sociologists of science acknowledge that, at least in certain stages of research, scientists are often reluctant to discuss their work with rivals. ${ }^{193}$ Moreover, there is reason to believe that secrecy is underreported by scientists who hesitate to acknowledge departures from scientific norms. ${ }^{194}$

Reluctance to acknowledge the prevalence of secrecy may have inhibited consideration of its possible benefits for research science. Ian Mitroff has cautiously suggested some possible functions of a "counter-norm" of secrecy in science on the basis of his interviews with Apollo moon scientists. ${ }^{195}$ He notes that although "[o]n the face of it, it would seem absurd to contend that there could be an opposing norm [to Merton's norm of communism] having some positive function in science," his data suggest that secrecy in science might serve as a protective device to prevent theft of ideas and to avoid disputes over priority, as well as serving as an ac-

192 See notes $120-26$ and sources cited therein.

${ }^{193}$ See, for example, Jerry Gaston, Originality and Competition in Science 116-29 (Chicago, 1973); Hagstrom, The Scientific Community at 88-98 (cited in note 3); Zuckerman, in Deviance and Social Change at 102-04 (cited in note 129); and Warren O. Hagstrom, Competition in Science, 39 Am Soc Rev 1, 8-10 (1974).

Zuckerman reconciles some instances of secrecy with the scientific norm of communism by noting that the Mertonian norms apply only to the "public" stages of science, when the research is ready for competent evaluation by peers in the scientific community. Zuckerman, in Deviance and Social Change at 103 (cited in note 129), citing Joseph Ben-David, Organization, Social Control and Cognitive Change in Science, in Joseph Ben-David and T. Clark, eds, Culture and its Creators: Essays in Honor of Edward Shils 244, 265 (Chicago, 1977).

${ }^{104}$ See Hagstrom, The Scientific Community at 88-89 (cited in note 3) (reporting inconsistent accounts of prevalence of secrecy by colleagues in the same departments, and suggesting that because it conflicts with scientific norms, "secrecy itself must usually be kept secret").

${ }^{105}$ Mitroff, The Subjective Side of Science at 75-79 (cited in note 130); and Mitroff, 39 Am Soc Rev at 591-93 (cited in note 130). 
knowledgement to oneself and others that one has work in progress that is worth protecting. ${ }^{196}$

Scientists depend on publication to establish their entitlements to recognition for their discoveries. Disclosure prior to publication leaves scientists vulnerable to having their ideas appropriated by others, preventing them from reaping the reward of recognition for priority of discovery. Pre-publication secrecy in research science may serve a function analogous to that of pre-patent secrecy in industrial research and development, supplying interim protection from free riders in order to preserve incentives to develop an idea that may not yet be protected in any other manner. ${ }^{107}$ If subsequent researchers needed to obtain permission from prior researchers before using their discoveries, they might have to disclose their ideas and plans to their research rivals. Since the scientific community does not recognize exclusive rights in research plans or ideas, these rivals would then be free to pursue the same research on their own and to publish the results without obligation to those whose unpublished ideas they pursued. Permitting free access to prior discoveries preserves the incentives of subsequent researchers to develop new research plans and ideas by allowing them to keep their plans and ideas to themselves until they are ready to publish their results in exchange for the reward of recognition. Allowing secrecy in the early stages of research may thus be a benefit rather than a drawback of a system that promotes individualism and independence in research, although it is not generally touted as such.

Even when secrecy and lack of coordination lead to duplicative research, such duplication is not necessarily wasteful. Robert Merton has identified several ways that having multiple scientists or teams of scientists work toward solutions of the same problem promotes the growth of knowledge. ${ }^{198}$ The less routine the scientific effort and the more far-reaching the implications of the results, the less likely it is that overlapping research efforts will prove wasteful. ${ }^{199}$ Multiple simultaneous research efforts enhance the likelihood that a problem will be solved quickly. ${ }^{200}$ Moreover,

198 Mitroff, 39 Am Soc Rev at 592-93 (cited in note 130).

197 See text accompanying note 223.

${ }^{108}$ Robert K. Merton, Multiple Discoveries as Strategic Research Site, in Merton, The Sociology of Science at 371, 378-81 (cited in note 2); and Merton, The Matthew Effect in Science, in Merton, The Sociology of Science at 439, 450-51 (cited in note 2). See also Hagstrom, $39 \mathrm{Am}$ Soc Rev at 15-16 (cited in note 193).

${ }_{109}$ Merton, in The Sociology of Science at 379 (cited in note 2).

200 Id at $378-79$. 
when multiple scientists arrive at the same conclusion, the redundancy improves the likelihood that the discovery will be incorporated in current scientific knowledge. ${ }^{201}$ Given the high volume of scientific literature competing for the attention of readers, new scientific information may need to be publicized repeatedly before it reaches and makes an impact on those who have a use for it..$^{202}$ Multiple independent discoveries help establish the validity of new research claims, serving as a substitute for after-the-fact replication. ${ }^{203}$ The lack of incentives to replicate already completed work may make simultaneous replication of research by competing scientists particularly important as a mechanism for validating research results.

Duplicative research efforts will rarely be entirely redundant. ${ }^{204}$ Different investigators working independently on the same problems will generally use somewhat different approaches and make different mistakes. ${ }^{205}$ If they obtain different results, more will be known than if only one of them had undertaken the investigation. Moreover, different investigators will often make different observations and draw different conclusions from the same data, particularly when an experiment leads to unexpected or anomalous

${ }^{201}$ Id at 380, 450; and Hagstrom, 39 Am Soc Rev at 15 (cited in note 193).

${ }^{202}$ See Herbert Menzel, Scientific Communication: Five Themes from Social Science Research, 21 Am Psychologist 999, 1000-01 (1966).

${ }^{203}$ Merton, in The Sociology of Science at 380 (cited in note 2).

${ }^{204}$ The value of overlapping research efforts is reflected in the high rate at which scientists publish research results even after they have been anticipated by others. In a survey of U.S. academic scientists, Warren Hagstrom found that 68-78 percent of experimental physicists, chemists, and biologists either published or planned to publish research results that had already been anticipated. Hagstrom, $39 \mathrm{Am}$ Soc Rev at 4 (Table 2) (cited in note 193). Roughly half of the scientists whose work had been anticipated published or planned to publish their results because their work was different from the previously published results, and a considerably smaller percentage published or planned to publish their work because of the value of replication. Id.

Unfortunately, Hagstrom's data do not distinguish between actual publications and mere plans to publish. Actual publications are a better measure of value than plans to publish, since actual publication requires a determination by peer reviewers that the research merits publication. Actual publications would also have a bearing on incentives to replicate previous scientific work. See notes 139-40 and accompanying text.

${ }^{203}$ Merton, in The Sociology of Science at $451 \mathrm{n} 30$ (cited in note 2) (quoting the following remarks by a Nobel laureate on duplication of research effort: "I think that if there are different groups in different laboratories working on the same thing, their approach is sufficiently different [to increase the probability of a successful outcome]. On the whole, this is a good thing and not something that should be avoided for the sake of efficiency.") (citing Harriet Zuckerman, Scientific Elite: Nobel Laureates in the United States (Free Press, 1977)). See also Feyerabend, in Criticism and the Growth of Knowledge at 204 (cited in note 179). 
results. ${ }^{206}$ Different investigators are also likely to perceive different implications for subsequent research in a single discovery. ${ }^{207}$

The fact that duplicative research efforts serve a valuable function does not necessarily argue against coordination of research efforts through a system of exclusive rights in research discoveries. To the extent that overlapping research efforts by different scientists promise to enhance the value of prior discoveries, one might expect the holders of exclusive rights in such discoveries to authorize such efforts willingly without a rule of free access. But coordinated research efforts cannot perform the same function as multiple independent, non-cooperative research efforts by competing investigators. Coordination is bound to compromise the independence of the researchers working on the problem and thereby reduce the efficiency of the overall effort. Moreover, a coordinated research effort is likely to involve like-minded scientists with a shared sense of purpose and shared intellectual commitments. Such scientists are less likely to see the limits of each other's approaches than are hostile rivals or scientists with different objectives and perspectives.

\section{Summary.}

Free access to prior discoveries performs a critical function in the system of social control in science by permitting scrutiny of research claims by scientific peers. It thereby allows the scientific community to challenge the validity of prior discoveries and to establish the value of the research contributions of its members. Free access also facilitates scientific progress by permitting subsequent investigators to use prior discoveries in their research without having to go to the trouble and expense of obtaining permission from their predecessors. It thereby lowers the costs of research and permits the simultaneous pursuit of divergent and even inconsistent approaches to further research emanating from prior discoveries. Finally, free access promotes scientific progress by fostering independence among scientists, allowing individual researchers to work

${ }^{208}$ Kuhn, Structure at 64 (cited in note 144) (noting that in normal science researchers often see only what is expected in their results, even under circumstances where scientists later perceive an anomaly).

${ }^{207}$ Hagstrom, $39 \mathrm{Am}$ Soc Rev at 15 (cited in note 193). See also Bernard Barber and Renee C. Fox, The Case of the Floppy-Eared Rabbits, in Bernard Barber and Walter Hirsch, eds, The Sociology of Science (Free Press, 1963) (comparing the research activities of two scientists who each accidentally collapsed rabbits' ears when injecting them intravenously with papain; only one of the scientists determined an explanation for this phenomenon through subsequent experiments). 
on the problems they choose in the manner they see fit without needing to obtain approval from other scientists who may disagree with their approaches, or having to disclose their plans to their research rivals.

\section{Integrating the Two Perspectives}

The discussion so far has presented divergent perspectives on how best to promote scientific progress, with divergent implications for whether patent holders should be able to enforce their exclusive rights against subsequent researchers. The economic justifications for granting exclusive rights in new discoveries considered in section I do not supply an argument for a research exemption from patent infringement liability and, on certain assumptions, seem to argue against such an exemption. On the other hand, the discussion in section II suggests a number of reasons for allowing researchers to enjoy free access to prior discoveries.

\section{A. Independence versus Coordination of Research}

The argument of the sociologists of science in favor of individualism and independence in research as a means of promoting progress conflicts with the prescription of the prospect theory in favor of coordination of research initiatives by patent holders. The prospect theory holds that such coordination promotes efficiency in research, while the arguments presented in section II suggest that coordination and control of research impedes progress and restricts individual initiative and creativity.

This contradiction may be explained in part by a difference in focus: the prospect theory is primarily concerned with promoting efficiency in research, while the argument for individualism and independence takes the promotion of scientific progress to be an unqualified goal. Thus it might be argued that even if greater scientific progress could be achieved through independent research initiatives in a system of free access to prior discoveries than through coordinated research efforts in a system of exclusive rights, the additional progress to be expected in the former type of system would not justify its greater costs in wasteful duplication of research effort.

But beyond this difference in focus there appear to be further differences in assumptions about the nature of research and the role of the individual researcher. The argument for independence among researchers makes more sense if research leads down unex- 
pected paths for which a course cannot be charted in advance, and if the success of research projects depends on insights and creativity that may differ from one investigator to the next. In these circumstances, individual investigators will be better able to make decisions about how to proceed with their own research projects than any outside supervisor or coordinator could be. ${ }^{208}$ On the other hand, the prospect theory might make more sense if research is a matter of systematic trial and error, in which the insights and creativity of individual investigators play little if any role. In these circumstances, there is little to be gained by leaving independent investigators to retrace each other's steps unwittingly, and the efficiency of the overall effort might be improved by placing the investigators under common supervision and control.

These different assumptions seem to correspond roughly to differences in the nature of research projects typically pursued in basic and applied research. ${ }^{200}$ The course of basic research projects tends to be less predictable than that of applied research projects, making coordination of research efforts more feasible and more beneficial in the latter context. For example, coordination of research efforts may be the most efficient way to develop a patented industrial machine to the point of commercial feasibility. So long as the subsequent research that is to be monitored and controlled by patent holders is a matter of routine trial and error, the efficiency gains from coordination probably outweigh any loss in individual productivity arising from impediments to creativity and initiative in coordinated research. Moreover, coordination and control offer greater benefits when researchers would otherwise be ignorant of each other's results. Basic researchers in academic institutions are likely to know of each other's research results from publications or informal communications and thus do not need outside coordinators to alert them to the achievements of their rivals, while applied researchers in industry are likely to work in secrecy

208 See notes $185-91$ and accompanying text.

${ }^{209}$ It is interesting that the advocates of these divergent perspectives do not confine their analyses to separate spheres of basic or applied research. Thus Kornhauser notes that bureaucratic control retards industrial research as well as academic research (see note 186), while Kitch suggests that coordination of research efforts might promote efficiency in basic research as well as in applied research. Kitch cites Robert Merton's account of the widespread phenomenon of "multiples" in scientific discovery and suggests that institutional mechanisms to reduce redundancy in basic research efforts would be desirable. Kitch, $20 \mathrm{~J} \mathrm{~L}$ \& Econ at 288-89 n 70 (cited in note 54), citing Merton, in The Sociology of Science at 281412 (cited in note 2). Kitch overlooks Merton's thoughtful rejection of this view in some of the cited pages. See notes 198-201, 203, and 205, and sources cited therein, and accompanying text. 
unless they are compelled to disclose their results and to coordinate their efforts in order to obtain patent licenses.

Independent, uncoordinated research efforts may be particularly important to the progress of science when the most promising course for subsequent research in the field of the invention is subject to dispute. In these circumstances, the arguments presented in section II suggest good reasons for believing that, if patent holders were given the power to coordinate and control access to their inventions by subsequent researchers, they would do more harm than good.

First, patent holders (or their scientific advisors) may have intellectual commitments that prevent them from seeing the merits of research proposals from scientists who do not share their basic viewpoints. ${ }^{210}$ They may therefore focus resources along lines of inquiry promising to confirm their own expectations and withhold approval from projects based on competing theories that strike them as less sound. A system of exclusive rights that allows prior researchers to coordinate and control the research of their successors may thus tend to reinforce prevailing viewpoints and hinder the advance of new ideas.

Second, scientists may be inclined to withhold their discoveries from their research rivals in order to enhance the likelihood that they and their collaborators will be first to make additional related discoveries in the future. ${ }^{211}$ The stakes of scientific rivalries could be magnified if future discoveries offered the promise of additional patent rights as well as further recognition in the scientific community, or if subsequent research threatened to destroy the value of the prior researcher's patent monopoly by rendering the patented invention technologically obsolete.

Third, even when lack of coordination of research efforts leads competing scientists to cover the same ground, it is not clear that the overlapping research efforts are wasteful from the standpoint of research science. ${ }^{212}$ Competing researchers will often have different backgrounds and ideas and use different techniques. Moreover, different investigators are likely to make different observations and have different ideas for follow-up experiments, improving the chances for serendipitous discoveries. Even completely duplicative research efforts may serve a valuable function by confirming research results and enhancing the likelihood that a discovery will be

${ }^{210}$ See notes 144-54 and accompanying text.

${ }^{211}$ See notes 171-72 and accompanying text.

212 See notes 198-207 and accompanying text. 
noticed. To the extent that patent rights serve to eliminate overlapping research efforts, they may be winnowing out a significant amount of wheat along with the chaff.

Coordination and control are most likely to improve efficiency for routine applied research projects, such as efforts to perfect a patented machine. But since the results of such routine research are unlikely to be patentable and will often fall squarely within the scope of the underlying patent claims, researchers are unlikely to invest in such improvements without first obtaining a license to exploit the underlying technology commercially, even if the research itself is exempt from infringement liability. ${ }^{213}$ Thus an experimental use exemption is unlikely to interfere with coordination and control of the type of research for which the prospect theory makes the most sense. In this context the prospect function should be self-enforcing whether or not patent holders have a legal right to stop subsequent researchers from developing their technological prospects.

The prospect theory offers a theoretical basis for arguing that patent holders should be allowed to control the use of their inventions in subsequent research in order to promote efficiency in the development of technological prospects. However, the courts have never embraced this theory, and commentators have criticized it on the ground that it rests on generally inaccurate assumptions about the operation of the patent system. ${ }^{214}$ The prospect theory also appears to rest on frequently inaccurate assumptions about the nature of research. When the results of following various research paths are uncertain and the discovery process involves a significant measure of individual creativity, it is unlikely that the overall efficiency of research would be improved by minimizing duplicative research efforts. The efficiency gains from coordinating research are likely to be greatest for routine applied research projects, but it is unlikely that an experimental use exemption would interfere with the ability of patent holders to monitor and control such research. One can therefore set aside objections to an experimental use exemption based on the premise of the prospect theory that it is desirable to permit patent holders to coordinate and control subsequent research in the field of the invention, and

23s See text accompanying note 118 and text following note 104 .

214 See notes 108, 114, and 117 and accompanying text, and sources cited therein. Specifically, these sources cast doubt on the validity of Kitch's assumptions that patents are typically issued long before commercialization of an invention and that patents typically extend protection to future related inventions. 
turn to a reconsideration of the traditional incentives justification for patent protection in light of the arguments for free access presented in section II.

\section{B. Ex Ante Incentives versus Subsequent Progress}

The argument that free access to prior discoveries promotes scientific progress by lowering the cost of research is in part the flip side of the argument that patents promote progress by offering monopoly profits as an incentive to make and disclose new inventions. ${ }^{215}$ These patent incentives depend on patent holders being able to charge higher prices as monopolists than they would receive under competitive conditions-but these higher prices necessarily entail higher costs to users of patented inventions. This dimension of the conflict between the two perspectives is to some extent unavoidable.

Nonetheless, the conflict might not be quite as intractable as it seems. To a certain extent, lawyers and economists calling for exclusive rights in discoveries as a means of promoting progress and sociologists of science praising free access to prior discoveries as a means of promoting progress are proceeding from different assumptions and analyzing different questions. For example, lawyers and economists often assume that the alternative to exclusive rights is secrecy, ${ }^{218}$ while sociologists of science tend to equate exclusive rights with secrecy and take the alternative to be free access to all prior discoveries. ${ }^{217}$ Thus a shared sense that secrecy hinders scientific progress leads these two groups of commentators to opposite positions on the desirability of exclusive rights.

Each of these assumptions about the relationship between secrecy and exclusive rights makes a certain amount of sense in some research settings. In strictly industrial research, often the only way to keep free riders from appropriating an unpatented invention is to keep it secret. Exclusive patent rights are seen as an alternative to secrecy because patent protection makes secrecy impossible (by requiring disclosure of the invention in order to get a patent) and unnecessary (by conferring exclusive rights that survive disclosure). By contrast, in strictly academic research exclusive rights

${ }^{218}$ Another dimension of the cost savings to research users from free access that does not correspond to profits for patent holders under a system of exclusive rights is the administrative costs involved in negotiating for licenses to use prior discoveries. See notes 164-65 and accompanying text.

${ }^{218}$ See notes $45-53$ and accompanying text.

${ }^{217}$ See notes 120-28 and accompanying text. 
that survive disclosure are virtually unheard of. ${ }^{218}$ Secrecy and exclusive rights tend to be equated because in most cases the only way to preserve exclusivity in an idea or discovery is to keep it secret. Disclosure through publication generally ends exclusivity by making the discovery freely available to the scientific community.

When patent protection extends into fields that are of interest to both academic and industrial scientists, neither of these assumptions about the relationship between exclusive rights and secrecy is quite right. On one hand, researchers who are motivated to earn scientific recognition may disclose their discoveries through publication even without patent protection, calling into question the assumption that exclusive patent rights are necessary to prevent secrecy. Eliminating or weakening patent protection in such fields might reduce disclosures of new discoveries from industrial laboratories, but some academic scientists would undoubtedly continue to make and disclose new discoveries in exchange for scientific rewards. On the other hand, patent protection brings about disclosure while conferring exclusive rights, calling into question the assumptions that exclusive rights are equivalent to secrecy and that disclosure is equivalent to free availability of research results. Patent protection can be expected to call forth disclosure of some new discoveries that otherwise might not be made or disclosed, while at the same time giving patent holders the right to restrict the use of these discoveries. Disclosure through the patent system in exchange for exclusive rights will generally be less valuable to subsequent researchers than disclosure through a scientific publication coupled with an unqualified right to use the invention in subsequent research. Subsequent researchers might nonetheless be able to obtain licenses to use patented inventions in their research, and the patent disclosure alone may sometimes benefit subsequent researchers even if they are unable to use the invention. ${ }^{219}$

It is also worth noting that, for many research uses of patented inventions, the theoretical conflict between free access and exclusive rights makes little practical difference. These include uses that either do not come to the attention of patent holders or, for whatever reason, do not provoke their objections. Making and using a patented invention within a research laboratory is not very

218 Scientists can sometimes preserve exclusivity after publication by withholding access to essential research materials, although this practice violates scientific norms. See Eisenberg, 97 Yale L J at 197-205 (cited in note 3).

219 For example, the disclosure of a patented invention might suggest to a subsequent researcher an experiment that could be performed without infringing the patent claims. 
conspicuous and may never come to the attention of the patent holder. Even if the patent holder knows about the use, it might not be worth the trouble and expense of pursuing a lawsuit against a researcher who does not represent a significant threat to the patent holder's commercial interests. Some patent holders might not object to the unlicensed use of their inventions in purely academic research with no commercial applications (at least so long as the lost royalties from such uses are insignificant), or in research in unrelated fields. Moreover, some patent holders might not object to the unlicensed use of their inventions in their own fields if they think the research might open up new markets for their inventions or improve upon them in ways that increase the value of their patent rights. ${ }^{220}$ If the patent holder does not object to the use, the research is likely to proceed with or without a license, whether or not it is exempt from infringement liability.

Patent protection will also not significantly restrict access by subsequent researchers to inventions that are readily available on the market from patent holders or their licensees at reasonable prices. For example, subsequent researchers who wish to use a patented chemical in their research can generally buy the product in the market at the same price that it is available to other consumers without having to explain what they want to do with it. The sale of a patented product, if authorized by the patent holder, carries with it an implied license to use the product. ${ }^{221}$ If the patent holder is charging a high enough price for the product, the researcher might find it cheaper to make the product herself, but the researcher's complaint in this context is no different than that of other consumers of patented inventions.

But not all patented inventions are readily available on a licensed basis in an anonymous market. Some patented products can only be obtained from the patent holder in a face to face transaction. It may also be necessary to negotiate with the patent holder in order to obtain a license to use a patented process. In these contexts some patent holders will undoubtedly object to the use of their inventions in subsequent research and, in the absence of an experimental use exemption, might use their exclusive rights to stop valuable research from proceeding. The risk that the parties

${ }^{220}$ For example, the value of the patent would increase if a researcher made unpatentable improvements in the invention that the patent holder was then free to use, so long as the original patent claims were broad enough that no one else could use the improved invention without a license from the patent holder.

221 United States $v$ Univis Lens Co., 316 US 241, 249 (1942). 
will be unable to agree on terms for a license is greatest when subsequent researchers want to use prior inventions to make further progress in the same field in competition with the patent holder, especially if the research threatens to render the patented invention technologically obsolete. ${ }^{222}$ In this situation the public interest in continued scientific progress after the patent issues conflicts with the patent holder's interest in prolonging the public's dependence on the patented technology. The patent holder will see the user as a competitor seeking to destroy the value of the patent monopoly rather than as another customer offering to contribute to monopoly profits, and it is unlikely that the patent holder would license the use unless compelled to do so.

One might object that if the subsequent research is truly valuable, the parties ought to be able to agree on license terms that would be profitable for both of them. But there are a number of reasons to believe that private bargaining between the parties in this context would not lead to an efficient outcome. First, uncertainty or disagreement as to the value of the patented invention, the likely outcome of the research project, and the validity and scope of the patent claims might make it difficult for the parties to agree on a price for a license. It might be possible to work around some of these problems through a license agreement that conditions royalty obligations on detailed contingencies, but negotiating the terms of such a license could be costly and burdensome. For research projects requiring access to many different patented inventions, these transaction costs could become insurmountable. Second, if the subsequent researcher and the patent holder are research rivals, the subsequent researcher might be reluctant to disclose valuable research plans to the patent holder in the course of negotiations for fear that the patent holder will pursue the research plans herself rather than extend a license to the researcher. ${ }^{223}$ In other words, it might be impossible for the subsequent researcher to obtain a license without disclosing valuable information that is not protectable as intellectual property. Subsequent researchers would have little incentive to apply their ingenuity to developing research plans involving the use of patented inventions if they could not protect those plans from appropriation by patent holders. Third, the loss of monopoly profits to the patent holder if the subsequent researcher succeeds in inventing around the patent may be greater than the anticipated profits to the sub-

212 See text accompanying note 79.

${ }^{223}$ See text accompanying note 197 . 
sequent researcher of using the new technology in competition with the patent holder, since the competitive technology will not give the subsequent researcher a monopoly while the prior patent holder remains in the market. In any of these circumstances, if the research is to proceed at all, it will probably have to be without the patent holder's permission.

But an exemption from infringement liability for research users would deprive patent holders of some of the social value of their inventions, thereby reducing the value of patents and weakening patent incentives. Whether such an exemption is nonetheless desirable in the interest of promoting continuing scientific progress is ultimately an empirical question.

\section{Recommendations}

An experimental use exemption seems most likely to undermine critical patent incentives when the researcher is an ordinary consumer of an invention with a primary or at least significant market among research users. For example, an exemption from infringement liability for research users of a patented laboratory machine would effectively eliminate the benefits of patent protection for the invention. ${ }^{224}$ Nor does it seem likely that a research exemption is necessary to ensure that scientists will have access to such an invention: the patent holder will see research users as potential customers rather than hostile rivals and will want to extend licenses to them in order to extract the full value of the patent monopoly.

The case for an experimental use exemption is strongest when the subsequent researcher is using a patented invention to check the validity of the patent holder's claims. Free access to patented inventions for the limited purpose of permitting scrutiny of new research claims serves the policies underlying the patent law as well as the interests of research science. Indeed, patent law promotes scrutiny of the research claims embodied in patented inventions through its requirement that patent holders make enabling

224 A similar reduction in the value of the patent monopoly might arise in the case of an invention that may be sold in its present form to non-research consumers, if the invention also has significant value as an input to subsequent research. For example, the value of a newly invented chemical may derive as much from its usefulness in facilitating the discovery of other chemicals in future research as from its usefulness in its present form to non-research consumers. If a patent on the chemical allowed the inventor to capture the value of the chemical to non-research consumers but not its value as an input to subsequent research, patent incentives to derive new chemicals would be reduced. 
disclosures of their inventions freely available to the public. ${ }^{225}$ Justice Story highlighted the importance of this interest in introducing the experimental use doctrine in Whittemore $v$ Cutter, ${ }^{226}$ noting that it should not constitute patent infringement to construct a patented machine "for the purpose of ascertaining the sufficiency of the machine to produce its described effects."227 Story's analysis suggests a function for the experimental use doctrine in the patent system that is analogous to that of replication of scientific experiments in the system of social control in science. Just as communitarian norms in science provide a check against fraud or error in research claims by subjecting research results to potential replication, free access to the enabling disclosures in issued patents provides a check against the issuance of a patent in exchange for disclosure of an inoperative invention by allowing interested members of the public to test patented inventions in their laboratories. ${ }^{228}$ If a patent disclosure proves inadequate to enable someone skilled in the field of the invention to reduce the invention to practice, the patent may be held invalid. ${ }^{229}$ Patent holders should not be able to use their exclusive rights to block such scrutiny.

The conflict between the interests of the patent holder and the interests of subsequent researchers seems most intractable when the researchers are rivals of the patent holder seeking to make further advances in the field of the invention. A research exemption in this context may be necessary in order to enable valuable subsequent research to proceed, yet allowing the researchers to avoid liability to the patent holder entirely would restrict the value of the patent monopoly and reduce ex ante incentives to make patentable inventions. An experimental use exemption in this context reduces the value of the patent monopoly in two ways. First, it deprives the patent holder of royalties that might otherwise be col-

${ }^{225}$ For an analysis of the interaction between the patent law enabling disclosure requirement and scientific norms concerning replicability of published research results, see Eisenberg, 97 Yale L J at 207-17 (cited in note 3).

228 29 F Cases 1120 (CC D Mass 1813).

${ }^{227}$ Id at 1121. See also Sawin v Guild, 21 F Cases 554, 555 (CC D Mass 1813) (noting that the making of a patented machine "to ascertain the verity and exactness of the specification" should not constitute infringement). For a fuller discussion of this aspect of the experimental use defense, see Eisenberg, 97 Yale L J at 220-22 (cited in note 3).

228 The prospect of invalidating an issued patent may fortify otherwise weak incentives for replication in science, making it worthwhile for competitors of the patent holder to test patented inventions in their laboratories notwithstanding the lack of scientific rewards for such an undertaking. See notes $138-40$ and accompanying text.

220 Grant $v$ Raymond, 31 US (6 Pet) 218, 247 (1832). See also Eisenberg, 97 Yale L J at 207-13 (cited in note 3). 
lected from researchers. Second, by lowering the cost to competitors of inventing around the patent, it shortens the expected duration of the patent holder's effective monopoly. On the other hand, an experimental use exemption lowers the costs of research at the same time that it lowers the expected returns from making patentable inventions. Thus an experimental use exemption might depress inventive activity by reducing patent incentives, while at the same time stimulating inventive activity by relieving researchers of the burden of paying royalties to prior researchers for access to their inventions. It is difficult to assess the net effect of such an exemption on willingness to invest in research.

Depending on the scope of the patent claims and the results of the subsequent research, it may not be necessary to give patent holders any remedy at all for the use of their inventions in research in order to protect their interests. For example, if a subsequent researcher develops an improvement that falls within the scope of the claims of the earlier patent, the financial interests of the patent holder may be adequately protected by allowing enforcement of the patent after the research is completed when the improvement is ready for commercial exploitation. So long as the subsequent researcher may not exploit the improvement commercially without a license from the patent holder, an experimental use exemption from infringement liability during the research stage would not deprive the patent holder of an opportunity to recover a fair share of the value of the improvement, and the exemption therefore should not undermine patent incentives. On the other hand, if the subsequent researcher is able to develop a substitute technology that does not infringe the patent claims, denying the patent holder a remedy for the research use could prevent the patent holder from earning an adequate return on the initial investment in developing the earlier patented invention.

It is often impossible to tell in advance whether a subsequent researcher's use of a patented invention will lead to an improvement falling within the scope of the claims of the prior patent or to a substitute technology falling outside the patent claims. The uncertainty arises in part because it is difficult to predict the course and outcome of research projects, and in part because it is difficult to determine the validity and scope of patent claims until these matters are resolved in litigation.

These difficulties argue against giving patent holders an injunctive remedy to prevent subsequent researchers from using their inventions to make further advances in the same field. Such a remedy would compel subsequent researchers to negotiate with 
their rivals for a license before they could use patented inventions in their research. Given the problems outlined above in negotiating for a license under these circumstances, it is likely that in many cases the parties would be unable to reach an agreement even though the subsequent research might offer significant social benefits. 230

Nonetheless, in some cases it may be appropriate for a court to require the researcher to pay a reasonable royalty to the patent holder after the fact in order to be sure that the patent holder is adequately compensated for the use of the patented invention. Damages for the research use may be unnecessary if the original patent is broad enough in scope to cover the improved technology developed by the researcher. In this situation, the patent holder's interests will be adequately protected by enforcement of the patent when the improved technology is ready for commercial exploitation. On the other hand, if the subsequent researcher uses the patented invention to invent around the patent, developing a new technology that may be exploited without infringing the patent claims, the patent holder will have no means of extracting payment from the researcher at the commercial exploitation stage. In

230 See text accompanying note 223. Denying injunctive relief against acts of patent infringement that further the public interest is not without precedent. Section 283 of the Patent Act allows the courts to grant injunctions in patent cases "in accordance with the principles of equity ... on such terms as the court deems reasonable." Patent Act, 35 USC § 283 (1982). Some courts have declined to enjoin acts of patent infringement when the defendant's use of the invention furthers an important public interest. See, for example, City of Milwaukee $v$ Activated Sludge, Inc., 69 F2d 577, 593 (7th Cir 1934) (reversing district court's grant of permanent injunction against infringement of patents relating to treatment of sewage because of public health interest in not having raw sewage disposed of in Lake Michigan, but affirming award of monetary damages); Vitamin Technologists, Inc. $v$ Wisconsin Alumni Research Foundation, 146 F2d 941, 956 (9th Cir 1944) (refusal of patent holder to license manufacturers of oleomargarine to use patented process of producing vita$\min D$ in food by exposing it to ultraviolet radiation justified denial of injunctive relief because of public interest in preventing disease of rickets among the poor, who are more likely to consume oleomargarine than butter). The courts more commonly invoke the public interest in denying a preliminary injunction than in denying a permanent injunction. See, for example, Datascope Corp. $v$ Kontron, Inc., 786 F2d 398, 401 (Fed Cir 1986) (affirming denial of preliminary injunction against infringement of patent on an intra-aortic balloon catheter on grounds, inter alia, that some patients would be harmed by unavailability of defendant's device); Scripps Clinic and Research Foundation v Genentech, Inc., $666 \mathrm{~F}$ Supp 1379, 1400-01 (N D Cal 1987) (denying preliminary injunction against infringement of patent on Factor VIII:C, a protein that plays an essential role in blood clotting, on grounds, inter alia, that hemophiliacs could suffer from delay in bringing defendant's potentially superior product on the market); Rohm and Haas Co. $v$ Mobil Oil Corp., 212 USPQ 354, 36465 (D Del 1981) (denying preliminary injunction against infringement of herbicide on grounds, inter alia, of adverse effects on farm economy and crop yields due to unavailability of herbicide). 
these circumstances, denying the patent holder a damage remedy for the research use would undermine the value of the patent monopoly and lead to unjust enrichment of the researcher.

Determination of reasonable royalties is never an easy task. When a patented invention is only one input in the development of a subsequent invention, the courts should be careful not to set damages at a level that deprives subsequent researchers of the rewards of their own superior insights or that makes it unprofitable to exploit the new technology. Another factor to bear in mind in awarding damages against subsequent researchers who use patented inventions in their research is that the same activities are generally perfectly legal in other countries. A United States patent does not confer the right to stop anyone from using the invention overseas, and the patent laws of many other nations recognize an experimental use exemption from infringement liability. ${ }^{231}$ Significant damage awards against U.S. researchers for infringement of U.S. patents could thus ultimately give foreign researchers an advantage over their U.S. competitors, leading companies to move their research operations overseas.

In sum, I make the following recommendations concerning the proper scope of an experimental use exemption from patent infringement liability:

(1) Research use of a patented invention to check the adequacy of the specification and the validity of the patent holder's claims about the invention should be exempt from infringement liability.

(2) Research use of a patented invention with a primary or significant market among research users should not be exempt from infringement liability when the research user is an ordinary consumer of the patented invention.

(3) A patent holder should not be entitled to enjoin the use of a patented invention in subsequent research in the field of the invention, which could potentially lead to improvements in the patented technology or to the development of alternative means of achieving the same purpose. However, it might be appropriate in some cases to award a reasonable royalty after the fact to be sure that the patent holder receives an adequate return on the initial investment in developing the patented invention. 


\section{IV: ILLUSTRATIONS}

The proper scope of an experimental use privilege may be clarified by considering specific patented inventions that have been or are likely to be used in subsequent research. Two recently issued patents with obvious implications for future biomedical research illustrate different ways in which the experimental use issue might arise. The first is a patent issued in 1982 and reissued in 1985 to Scripps Clinic and Research Foundation (Scripps) on a purified protein that is essential for blood clotting. ${ }^{232}$ This patent is the subject of a recent patent infringement action brought by Scripps against Genentech, Inc. ${ }^{233}$ The second is a patent issued in 1988 to Harvard University on genetically engineered, non-human mammals containing a recombinant DNA sequence making them susceptible to cancer. ${ }^{234}$

\section{A. Factor VIII:C}

The blood clotting factor patents arose out of the development by Scripps scientists of a process for purifying and concentrating Factor VIII:C, a protein that plays an essential role in blood clotting, from human and animal blood plasma. ${ }^{235}$ The patents include claims to both the process of purifying Factor VIII:C and the highly purified and concentrated Factor VIII:C product itself. ${ }^{236}$

232 US Patent No 4,361,509, 1024 Official Gazette of the US Patent \& Trademark Office 1708 (Nov 30, 1982), and Reissue Patent No RE 32,011, 1059 Official Gazette 1485 (Oct 22, 1985).

${ }^{233}$ Scripps Clinic and Research Foundation v Genentech, Inc., No. C-83-5423-WWS (N D Cal, Nov 1983). See Scripps Clinic and Research Foundation v Genentech, Inc., 666 F Supp 1379 (N D Cal 1987), modified in 678 F Supp 1429 (N D Cal 1988). See also 707 F Supp 1547 (N D Cal 1989) (holding patent claims invalid).

${ }^{234}$ US Patent No 4,736,866, 1089 Official Gazette of the US Patent \& Trademark Office 703 (April 12, 1988). This is the notorious "mouse patent" that made headline news for being the first patent issued on an animal. Keith Schneider, Harvard Gets Mouse Patent, A World First, NY Times A1 (April 13, 1988).

${ }^{236}$ See Scripps, 666 F Supp at 1383. Factor VIII:C as it is normally found in blood is attached to another protein known as Factor VIII:RP. The purification method developed by the Scripps scientists involves using monoclonal antibodies to Factor VIII:RP to isolate the Factor VIII:C/VIII:RP complexes from blood plasma and then washing the complexes with a salt solution to break the bonds between the two proteins. Id.

Scripps extended an exclusive license under the patent to Revlon, Inc. Id at 1382.

236 Claim 1 is typical of the process claims. It reads as follows:

An improved method of preparing Factor VIII procoagulant activity protein comprising the steps of (a) adsorbing a VIII:C/VIII:RP complex from a plasma or commercial concentrate source onto particles bound to a monoclonal antibody specific to VIII:RP, (b) eluting the VIII:C, (c) adsorbing the VIII:C obtained in step (b) in another adsorption to concentrate and further purify same, (d) eluting the adsorbed VIII:C, and (e) recovering highly purified and concentrated VIII:C. 
The product claims are not limited to Factor VIII:C produced by the patented process, ${ }^{237}$ but extend to Factor VIII:C of a specified range of purity and potency however prepared. ${ }^{238}$

Factor VIII:C occurs naturally in minute quantities in blood, making it necessary to pool blood plasma from a large number of donors in order to produce concentrated and purified Factor VIII:C by the Scripps method. As a consequence, Factor VIII:C produced by this method is expensive and carries a risk that it harbors infectious agents such as viruses from the blood of any one of many donors. ${ }^{238}$ These considerations make the protein an attractive candidate for recombinant DNA production.

Scientists at Genentech began research to produce Factor VIII:C through recombinant DNA technology before the Scripps patent issued and continued their efforts into the patent term. ${ }^{240}$ In the course of their research the Genentech scientists used purified Factor VIII:C prepared by the Scripps method as well as by other methods. Although at the time of the lawsuit Genentech had not yet produced Factor VIII:C in commercial quantities, its scientists had produced small quantities of the protein in cell culture and had purified the recombinant protein harvested from the culture through the use of antibodies. Genentech entered into a research and development contract with Cutter Laboratories calling for development of a method for commercial scale production of recombinant Factor VIII:C for future clinical testing. ${ }^{241}$

Scripps sued Genentech for patent infringement, seeking damages and an injunction against further use by Genentech of puri-

Id at 1385.

${ }^{237}$ Claim 13, which covers the purified protein produced by this process, reads as follows:

Highly purified and concentrated human or porcine VIII:C prepared in accordance with the method of claim 1.

Id.

2ss Claim 24, which exemplifies the breadth of coverage, reads as follows:

A human VIII:C preparation having a potency in the range of 134 to 1172 units per ml. and being substantially free of VIII:RP. Id.

A newly isolated, naturally occurring product may be patented if the applicant has not merely invented a new means of producing an old product but has actually created a new product that did not previously exist in nature in the same form. See, for example, Merck \& Co. $v$ Olin Mathieson Chemical Corp., 253 F2d 156 (4th Cir 1958) (upholding validity of patent on Vitamin B12 concentrate obtained by extraction and purification from fermentation materials, where patented product differed in its therapeutic effects from previously available, impure Vitamin B12 obtained from liver extracts).

${ }^{238}$ Scripps, 666 F Supp at 1384.

${ }^{240}$ Id.

241 Id at 1384-85. 
fied Factor VIII:C. The district court granted summary judgment in favor of Scripps on the issue of infringement, ${ }^{242}$ although in a subsequent decision the same court held the patent claims involved in the lawsuit invalid. ${ }^{243}$ In the earlier decision finding that the claims, if valid, were infringed, the court construed the claims as extending to any purified Factor VIII:C regardless of the method of its preparation. The court found that Genentech's production of recombinant and plasma-derived Factor VIII:C in the laboratory and use of these products in its research infringed the patent. 244 Nonetheless, the court declined to enter a preliminary injunction, finding that Scripps had failed to establish a reasonable likelihood of prevailing on the issue of patent validity, and that the public interest in the development of recombinant Factor VIII:C argued against enjoining further research until Genentech had an opportunity to produce evidence of invalidity. ${ }^{245}$

Genentech did not raise the experimental use defense and, in view of its undisputed commercial purpose in pursuing the research, the defense probably would not have succeeded. ${ }^{246}$ Nonetheless, the case presents appropriate facts for a denial of injunctive relief under the analysis suggested in this article. This is an example of researchers using a patented invention to make further progress in the same field in competition with the patent holder. Genentech's research activities, although hostile to the commercial

242 Id at 1389, 1395.

${ }^{243}$ Scripps, 707 F Supp 1547 (cited in note 233).

244 Scripps, 666 F Supp at 1389-95.

${ }^{245}$ Id at 1401. Genentech ultimately succeeded in its challenge to the validity of the patent claims on grounds of anticipation, inequitable conduct, and violation of the best mode requirement. Scripps, 707 F Supp 1547.

${ }^{246}$ Genentech instead argued, unsuccessfully, that its use of Factor VIII:C fell within the exception to infringement liability provided in 35 USC $\$ 271(\mathrm{e})(1)$ for the use of a patented invention "solely for uses reasonably related to the development and submission of information under a Federal law which regulates the manufacture, use, or sale of drugs." Scripps, 666 F Supp at 1395-96. See note 6 and sources cited therein. The court rejected this argument on the ground that Genentech's use of Factor VIII:C was not solely related to meeting FDA requirements, but also related to preparation of an application for a European patent, performance of Genentech's agreement with Cutter Laboratories, and "marketing of recombinant Factor VIII:C outside the United States before expiration of the Scripps patent." Id at 1396. Although Genentech has not yet begun commercial production of Factor VIII:C, it has made arrangements to produce the protein in sufficient quantities for use in clinical trials with the ultimate goal of selling it for the treatment of hemophiliacs. Use of a patented drug to conduct clinical trials was held to be a commercial use falling outside the protection of the experimental use defense in Roche Products, Inc. $v$ Bolar Pharmaceutical Co., 733 F2d 858, 862-63 (Fed Cir 1984). Although the specific holding of this case has since been abrogated by statute, the experimental use aspect of the decision remains intact. See 35 USC $\$ 271(\mathrm{e})$. See also cases cited in note 8 (denying experimental use exemption where research use was motivated by commercial purpose). 
interests of Scripps, clearly furthered the public interest in promoting scientific progress. Recombinant Factor VIII:C promises to be both cheaper and safer than Factor VIII:C purified from blood plasma in accordance with the Scripps method. Moreover, cloning the Factor VIII:C gene represented a significant scientific achievement. ${ }^{247}$ But since Genentech is a research and commercial competitor of the patent holder, it is unlikely that the use would be licensed in the absence of an exemption from liability.

Since the Scripps patent claims, if valid, would have been broad enough to cover recombinant Factor VIII:C, one might expect that Scripps would be delighted to have Genentech invest in developing an improved method of making its patented invention and that, conversely, Genentech would have little interest in sponsoring such an effort without first being assured of a license under the Scripps patent. But although the broad product claims seem to protect Scripps from the possibility that Genentech would invent around its patent, the invention of recombinant Factor VIII:C nonetheless has value that both parties would like to capture for themselves. Assuming that recombinant Factor VIII:C is a patentable improvement over the purified Factor VIII:C obtained by the Scripps method, both Scripps and Genentech stand to benefit from making and patenting this invention. If Genentech were able to develop and patent recombinant Factor VIII:C first, neither Scripps nor Genentech could make the recombinant product commercially without a license from the other. Holding a patent on recombinant Factor VIII:C would thus improve considerably Genentech's bargaining position in negotiating with Scripps for a license to share in the Factor VIII:C market. On the other hand, if Scripps made the invention first, it could exploit the improved product on its own without needing to obtain a license from Genentech. Thus, even though Scripps's patent gives it considerable protection against competitors in the Factor VIII:C market, it might nonetheless choose to prevent Genentech from competing to make recombinant Factor VIII:C if the patent laws permit it to do so.

At the same time, Genentech might be reluctant to seek a license from Scripps to pursue its research for fear of tipping its hand to a research rival. Scripps would in all likelihood want to know what Genentech planned to do with the invention before it would be willing to extend a license, but once Genentech disclosed

${ }^{247}$ Factor VIII:C was much larger than any protein previously produced through recombinant DNA technology. Scripps, 666 F Supp at 1384. 
its plans to Scripps, Scripps could pursue the research on its own, depriving Genentech of the rewards of its own ingenuity.

Moreover, even with broad patent claims Scripps might not be sure that the claims would be held valid in litigation or that Genentech would not manage to invent around the patent, thereby destroying its monopoly position. The distinction between research that will yield improvements falling within the scope of patent claims and research that will yield alternative technologies falling outside the scope of the claims is difficult to draw in advance, and patent holders who have the power to enjoin the use of their inventions in research in the same field might play it safe by forbidding all such research. Moreover, the scope of patent claims is often uncertain until the claims are construed in litigation. Genentech made a colorable, although unsuccessful, argument that recombinant Factor VIII:C did not fall within the scope of the patent claims, and ultimately succeeded in having the claims that it was charged with infringing declared invalid. ${ }^{248}$ Thus even if one could foresee in advance the likely outcome of a research project in the field of a patented invention, it still might not be possible to determine with any certainty whether that outcome could be exploited without infringing the patent claims. This uncertainty would add to the difficulties of negotiating a license.

It might seem wasteful to have Scripps and Genentech scientists competing to develop recombinant Factor VIII:C. But since we know with the benefit of hindsight that Genentech made the improvement first, its efforts obviously were not entirely redundant to those of Scripps and its licensees. The district court acknowledged the public interest in rapid development of recombinant Factor VIII:C in declining to enter a preliminary injunction against Genentech. One can only speculate as to how much longer the public would have to wait for this and other improvements to patented inventions if patent holders could block their rivals from competing with them in research. Given that patent holders have an interest in prolonging the period of the public's dependence on patented technologies and given the difficulty of foreseeing the outcome of future research projects in the fields of patented inventions, it seems imprudent to place this power in the hands of patent holders.

Inasmuch as the court ultimately held all of the claims at issue in the lawsuit invalid, Scripps did not obtain any remedy at all. On

248 Scripps, 707 F Supp 1547 (N D Cal 1989). 
the other hand, had the court upheld the validity of claims covering the recombinant Factor VIII:C, it would not have been necessary to award damages for Genentech's use of the patented invention in research, since Scripps's interests could be protected adequately by allowing it to enforce its patent against Genentech at the commercial exploitation stage. A more difficult question would have been presented if the court had upheld the validity of claims that were infringed only at the research stage, while holding invalid any claims that would still be infringed at the stage of commercial exploitation. For example, suppose the court had upheld the validity of Scripps's claims to its process of purifying Factor VIII:C-a process which Genentech had used only in its research-and had held invalid the product claims that would have covered the recombinant product that Genentech planned to sell commercially. In that case it might have been appropriate to award damages to Scripps for the research use in order to ensure that Scripps captured a fair share of the value that its validly patented process contributed to Genentech's research.

\section{B. Transgenic Mammals}

The transgenic mammals patent arose out of the development by scientists at Harvard University of a mouse that was genetically altered with a human cancer gene. ${ }^{249}$ As a result of this genetic alteration, the mouse is unusually susceptible to developing breast cancer. Harvard has granted an exclusive license under the patent to duPont Co. to produce transgenic mice for use in research. ${ }^{250}$ DuPont recently announced that it plans to begin marketing transgenic mice to cancer researchers in nonprofit and government laboratories next year. The mice will sell for approximately $\$ 50$ each. ${ }^{251}$

In this case the claimed invention is primarily a research tool,

249 Although the specific embodiment of the invention achieved by the Harvard scientists was a transgenic mouse, the scope of the patent claims is not limited to transgenic mice. Claim 1 of the patent reads as follows:

A transgenic non-human mammal all of whose germ cells and somatic cells contain a recombinant activated oncogene sequence introduced into said mammal, or an ancestor of said mammal, at an embryonic stage.

US Patent No 4,736,866, at 9-10 (cited in note 234). Other claims define the invention more narrowly, limiting it to transgenic "rodents" or "mice." The breadth of claim 1 brings a wide range of possible subsequent advances in the field of transgenic mammals within the scope of the patent monopoly.

250 Telephone interview with Joyce Brinton, Harvard University Office of Patents, Copyrights \& Licensing, April 18, 1988.

${ }^{251}$ DuPont Co. to Sell Gene-Spliced Mice to Scientists in Labs Studying Cancer, Wall St J B5 (Nov 16, 1988). 
to be produced commercially for sale to researchers. The transgenic mice have a variety of uses in research. They could serve as living models for studying the cancer-causing or cancer-inhibiting effects of various agents, or for studying the mechanisms by which genes contribute to the development of cancer. They might also be useful to scientists trying to design other transgenic mammals.

Researchers who are using transgenic mice to study cancer are potential customers for the patented invention. If such users were exempt from the patent monopoly, it would be difficult for Harvard and duPont to extract royalties from a significant segment of the market for the patented invention. Researchers might still choose to buy the duPont mice rather than making their own, especially if there are economies of scale that make duPont a more efficient producer. But if researchers were free to make the mice on their own, duPont would be limited to charging no more than the cost to researchers of making the mice in their own laboratories. This could potentially restrict the monopoly profits to be made from the patent and thereby undermine patent incentives.

Denying these researchers an exemption from infringement liability is unlikely to deprive them of the use of transgenic mice in their research. They will simply have to pay the price that duPont charges for the mice. ${ }^{252}$ DuPont will want to sell to these users-they fall squarely within the market for the patented invention. The experimental use exemption should not permit ordinary consumption of a patented invention by research users without a license from the patent holder.

On the other hand, researchers in the transgenic mammals field who are trying to design a better transgenic laboratory mammal, or a transgenic mammal that does not infringe the patent, should not need to negotiate for a license before they can proceed with their research, ${ }^{253}$ although they might be held liable for dam-

${ }^{252}$ A more compelling case for an experimental use exemption might be presented in the case of a research technology invention that is not available by license. For example, suppose Harvard were to decide to give its own researchers exclusive access to transgenic mammals as a research tool. In this case, as in the case of research in the field of the patented invention, the patent holder sees research users primarily as competitors rather than as consumers. When this happens, it is at least arguable that some sort of experimental use exemption may be necessary to prevent patent holders from using their monopolies to block the technological progress of their rivals.

${ }^{253}$ If duPont made the mice readily available to all researchers on the same terms, there might be no need to exempt competitive researchers from the patent monopoly. On the other hand, researchers studying how to make transgenic mammals might have legitimate research reasons for wanting to make the mammals themselves, or they might want to make mammals that are different from those sold by duPont, but nonetheless fall within the 
ages after the fact. Such research is comparable to the efforts of Genentech to develop recombinant Factor VIII:C and should not be subject to the control of the patent holder for the reasons outlined above. ${ }^{254}$ Patent holders should not be able to enjoin the use of their inventions in subsequent research in the same field by their rivals.

\section{Conclusion}

The patent system aims to promote scientific and technological progress by granting exclusive rights in new discoveries. But the enforcement of these exclusive rights against subsequent researchers can sometimes interfere with further progress in the field of the invention. The literature in the sociology, history, and philosophy of science offers a number of reasons for believing that free access to prior discoveries by subsequent researchers might be a more effective means of promoting progress. In some respects these two perspectives on how best to promote progress are irreconcilable, with each perspective making sense in its own distinct sphere of basic or applied research. But as the line between basic and applied research becomes blurred in certain fields, patent protection increasingly threatens to encroach on the domain of research science, making it necessary to work out an accommodation between the two perspectives. A carefully formulated experimental use exemption from patent infringement liability is an important first step in that direction. 